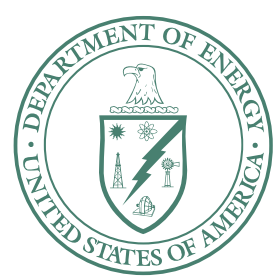

U.S. Department of Energy

Idaho Operations Office

\title{
Groundwater Monitoring and Field Sampling Plan for Operable Unit 10-08
}

May 2007 
DOE/NE-ID-11210

Revision 2

Project No. 23368

\section{Groundwater Monitoring and Field Sampling Plan for Operable Unit 10-08}

May 2007

Prepared for the 



\begin{abstract}
This plan describes the groundwater sampling and water level monitoring that will be conducted to evaluate contaminants in the Snake River Plain Aquifer entering and leaving the Idaho National Laboratory. The sampling and monitoring locations were selected to meet the data quality objectives detailed in this plan. Data for the Snake River Plain Aquifer obtained under this plan will be evaluated in the Operable Unit 10-08 Remedial Investigation/Feasibility Study report and will be used to support the Operable Unit 10-08 Sitewide groundwater model.
\end{abstract}




\section{CONTENTS}

ABSTRACT iii

ACRONYMS ix

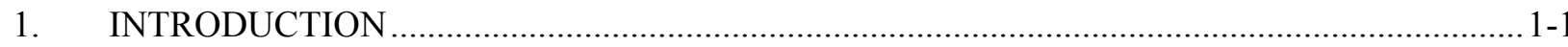

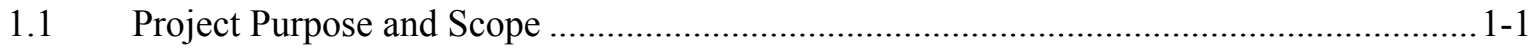

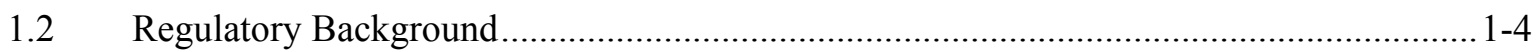

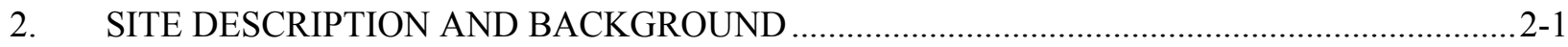

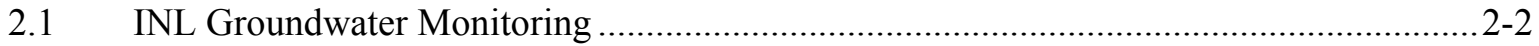

2.2 Previous Operable Unit 10-08 Sampling.....................................................................

2.2.1 Data Summary for Previous OU 10-08 Sampling Events ...............................2-6

2.2.2 Data Summary for Explosive Sampling Events ............................................2-6

2.3 Other Studies Relevant to Operable Unit 10-08 ….......................................................

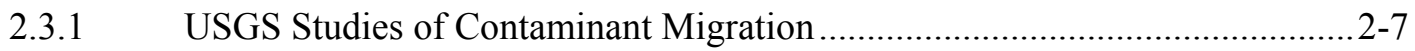

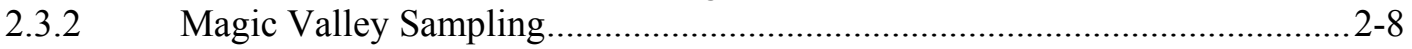

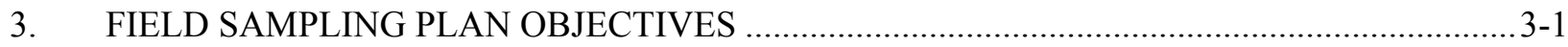

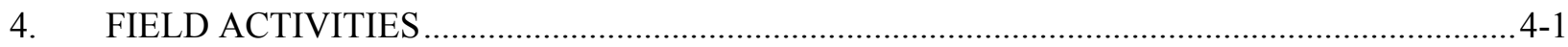

4.1 Routine Sampling Locations and Laboratory Analytes............................................... 4-1

4.1.1 Sampling Locations for Fiscal Year 2007 .......................................................4-1

4.1.2 Sampling Locations for Fiscal Year 2008 and until the OU 10-08 Record of Decision ............................................................................................ $4-4$

4.1.3 Analytes for the OU 10-08 Remedial Investigation/Feasibility Study.............4-5

4.1.4 Operable Unit 10-08 Sampling Schedule...................................................... 4-5

4.2 Sampling Quality Assurance/Quality Control and Performance Evaluation Samples ....... 4-5

4.3 Water Level Measurement Locations and Schedule ..................................................... 4-8

5. GROUNDWATER SAMPLING PROCEDURES AND EQUIPMENT .................................... $5-1$

5.1 Groundwater Elevations ..................................................................................... $5-1$

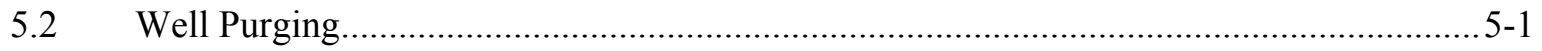

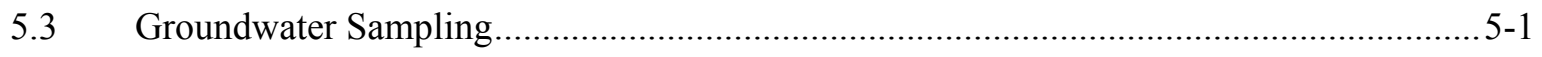

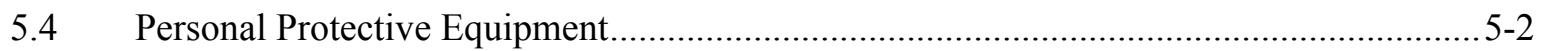




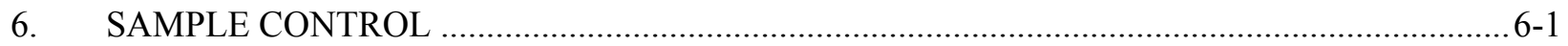

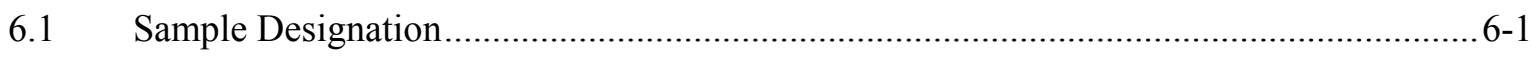

6.1.1 Sample Identification Code ....................................................................... 6-1

6.1.2 Sampling and Analysis Plan Table/Database ............................................... 6-1

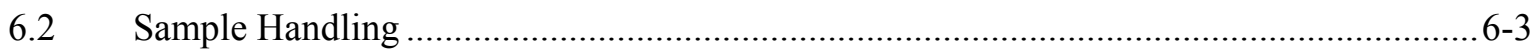

6.2.1 Sample Preservation.............................................................................. 6-3

6.2.2 Chain-of-Custody Procedures …….................................................................. 6-3

6.2.3 Transportation of Samples ...................................................................... 6-3

7. QUALITY ASSURANCE/QUALITY CONTROL ...............................................................

7.1 Project Quality Objectives..................................................................................

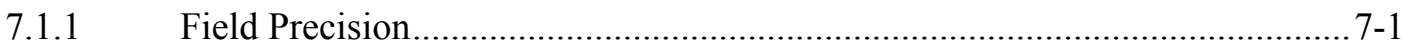

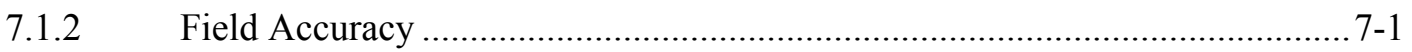

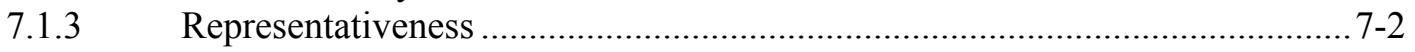

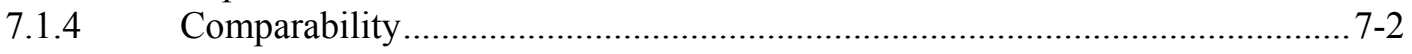

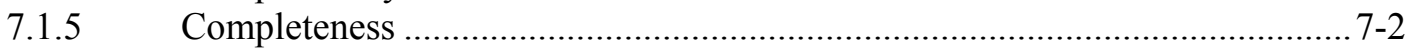

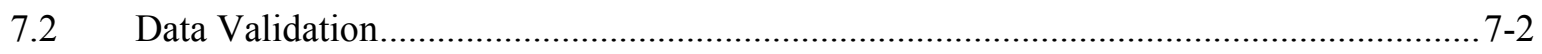

7.3 Quality Assurance Objectives for Measurement ...................................................... 7-2

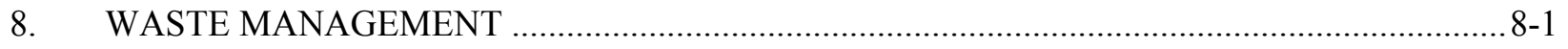

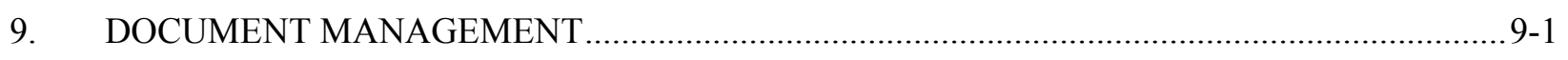

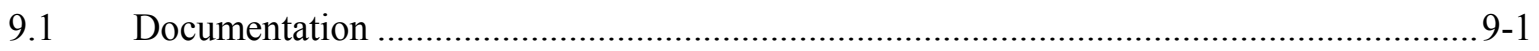

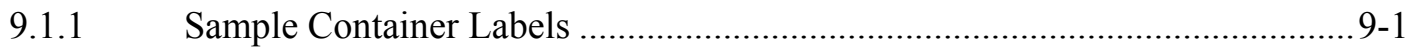

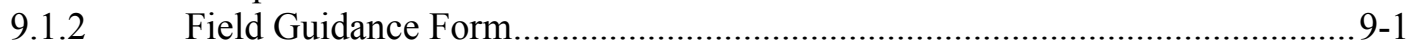

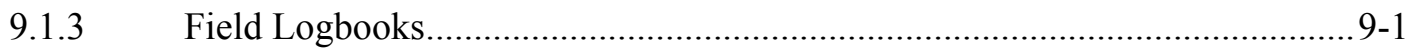

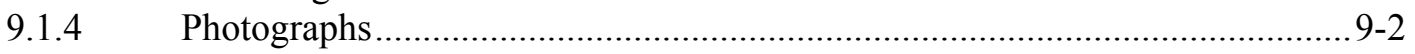

9.2 Document Revision Requests.............................................................................. $9-2$

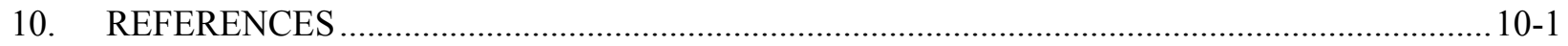




\section{FIGURES}

1-1. Idaho National Laboratory site map showing Waste Area Group locations .................................1-2

2-1. Map showing water table contours for the Snake River Plain Aquifer underneath the INL Site ....2-1

2-2. Map showing the locations of baseline, boundary, and guard wells sampled at the INL Site in 2003 and 2004

2-3. Map showing the locations of baseline, boundary, guard, and distal wells sampled at the INL Site in 2005 .....

2-4. Map showing the locations of baseline, boundary, guard, and distal wells sampled at the INL Site in 2006

4-1. Locations and sampling frequency for wells to be sampled for the Operable Unit 10-08 Remedial Investigation/Feasibility Study

4-2. Location of wells in automated water-level monitoring network

\section{TABLES}

3-1. Data quality objectives for groundwater monitoring associated with Operable Unit 10-08 groundwater monitoring

4-1. Specific well information

4-2. Groundwater contaminants of concern identified in existing Records of Decision at the INL Site

4-3. Operable Unit 10-08 analytes and required quantitation levels 


\section{ACRONYMS}

\begin{tabular}{|c|c|}
\hline AMS & accelerator mass spectrometry \\
\hline bgs & below ground surface \\
\hline CERCLA & Comprehensive Environmental Response, Compensation, and Liability Act \\
\hline CFA & Central Facilities Area \\
\hline $\mathrm{CFC}$ & chlorofluorocarbon \\
\hline CFR & Code of Federal Regulations \\
\hline $\mathrm{CoC}$ & chain of custody \\
\hline $\mathrm{COC}$ & contaminant of concern \\
\hline COPC & contaminant of potential concern \\
\hline DEQ & [Idaho] Department of Environmental Quality \\
\hline DOE & U.S. Department of Energy \\
\hline DOE-ID & Department of Energy Idaho Operations Office \\
\hline DOT & Department of Transportation \\
\hline DQO & data quality objective \\
\hline DR & decision rule \\
\hline EPA & U.S. Environmental Protection Agency \\
\hline $\mathrm{FFA} / \mathrm{CO}$ & Federal Facility Agreement and Consent Order \\
\hline FTL & field team leader \\
\hline FY & fiscal year \\
\hline HASP & health and safety plan \\
\hline ICP & Idaho Cleanup Project \\
\hline INEEL & Idaho National Engineering and Environmental Laboratory \\
\hline INL & Idaho National Laboratory \\
\hline INTEC & Idaho Nuclear Technology and Engineering Center \\
\hline MCL & maximum contaminant level \\
\hline MFC & Materials and Fuels Complex \\
\hline OU & operable unit \\
\hline
\end{tabular}




$\begin{array}{ll}\text { PCE } & \text { tetrachloroethene } \\ \text { PE } & \text { performance evaluation } \\ \text { PPE } & \text { personal protective equipment } \\ \text { PSQ } & \text { principal study question } \\ \text { QA/QC } & \text { quality assurance/quality control } \\ \text { QAPjP } & \text { quality assurance project plan } \\ \text { RI/FS } & \text { remedial investigation/feasibility study } \\ \text { ROD } & \text { Record of Decision } \\ \text { RTC } & \text { Reactor Technology Complex (formerly Test Reactor Area [TRA]) } \\ \text { RWMC } & \text { Radioactive Waste Management Complex } \\ \text { SAM } & \text { Sample and Analysis Management } \\ \text { SAP } & \text { sampling and analysis plan } \\ \text { SDWS } & \text { secondary drinking water standard } \\ \text { SRPA } & \text { Snake River Plain Aquifer } \\ \text { TAN } & \text { Test Area North } \\ \text { TCE } & \text { trichloroethene } \\ \text { USGS } & \text { United States Geological Survey } \\ \text { VOC } & \text { volatile organic compound } \\ \text { WAG } & \text { waste area group } \\ \text { WGS } & \text { Waste Generator Services } \\ & \end{array}$




\section{Groundwater Monitoring and Field Sampling Plan for Operable Unit 10-08}

\section{INTRODUCTION}

A number of radioactive and hazardous contaminants have been found in the Snake River Plain Aquifer (SRPA) beneath the Idaho National Laboratory (INL) Site. Many of these contaminants are the result of INL operations conducted over the past 50 years. The potential impacts to the groundwater from these INL activities are under investigation by Operable Unit (OU) 10-08. The critical importance of the SRPA to the residents of eastern Idaho has been recognized by the U.S. Environmental Protection Agency (EPA) with the SRPA's designation as a sole-source aquifer.

Investigation and cleanup of contaminated areas at the INL Site are performed within the framework of the Federal Facility Agreement and Consent Order for the Idaho National Engineering Laboratory (FFA/CO) (DOE-ID 1991) and the Comprehensive Environmental Response, Compensation, and Liability Act (CERCLA) (42 USC § 9601 et seq.). Within this framework, the INL Site is divided into 10 "waste area groups" (WAGs), and each WAG is further divided into more manageable "operable units" (OUs).

WAG 10 at the INL Site encompasses miscellaneous surface-contamination sites and liquid-disposal areas that are outside the boundaries of the INL's other nine WAGs (Figure 1-1). The OU 10-08 addresses potential contamination issues associated with the SRPA, which are outside the purview of the other WAGs. A major component of the OU 10-08 remedial investigation/feasibility study (RI/FS) is a numerical model to predict contaminant transport in the aquifer and calculate risk from groundwater use. Operable Unit 10-08 also includes new sites discovered within the other WAGs after their Records of Decision (RODs) have been signed.

\subsection{Project Purpose and Scope}

This plan establishes the groundwater monitoring and sampling requirements for the OU 10-08 RI/FS. Operable Unit 10-08 is responsible for determining the nature and extent of contamination in the SRPA from INL operations and the resulting potential risks to human health and the environment. The results of the groundwater sampling will be used to help ensure that environmental impacts associated with releases of hazardous substances at the INL Site are thoroughly investigated and appropriate actions are taken to protect the public and the environment, as set forth in the FFA/CO (DOE-ID 1991) and CERCLA (42 USC $\S 9601$ et seq.).

The comprehensive nature and scope of OU 10-08 necessitates that monitoring data be collected over many years and long-term integration be maintained among individual WAGs in order to ensure that the data needed is available and of sufficient quality for preparation of the comprehensive RI/FS. The large area encompassed by OU 10-08 (i.e., the entire 890- $\mathrm{mi}^{2}$ INL Site) and the long groundwater travel times across the area require monitoring of water quality and water levels over many years to correctly and adequately characterize the SRPA for risk-assessment calculations. In addition, it is critical that the OU 10-08 groundwater monitoring program interface with groundwater monitoring by individual WAGs to create a synergistic and integrated understanding of the SRPA flow regime, contaminant source terms, and subsurface transport within the INL Site boundaries. Results from the data collected under this plan will support development of the OU 10-08 groundwater conceptual model and will be used to calibrate the numerical groundwater model. An integrated understanding of the overall quality of the SRPA 


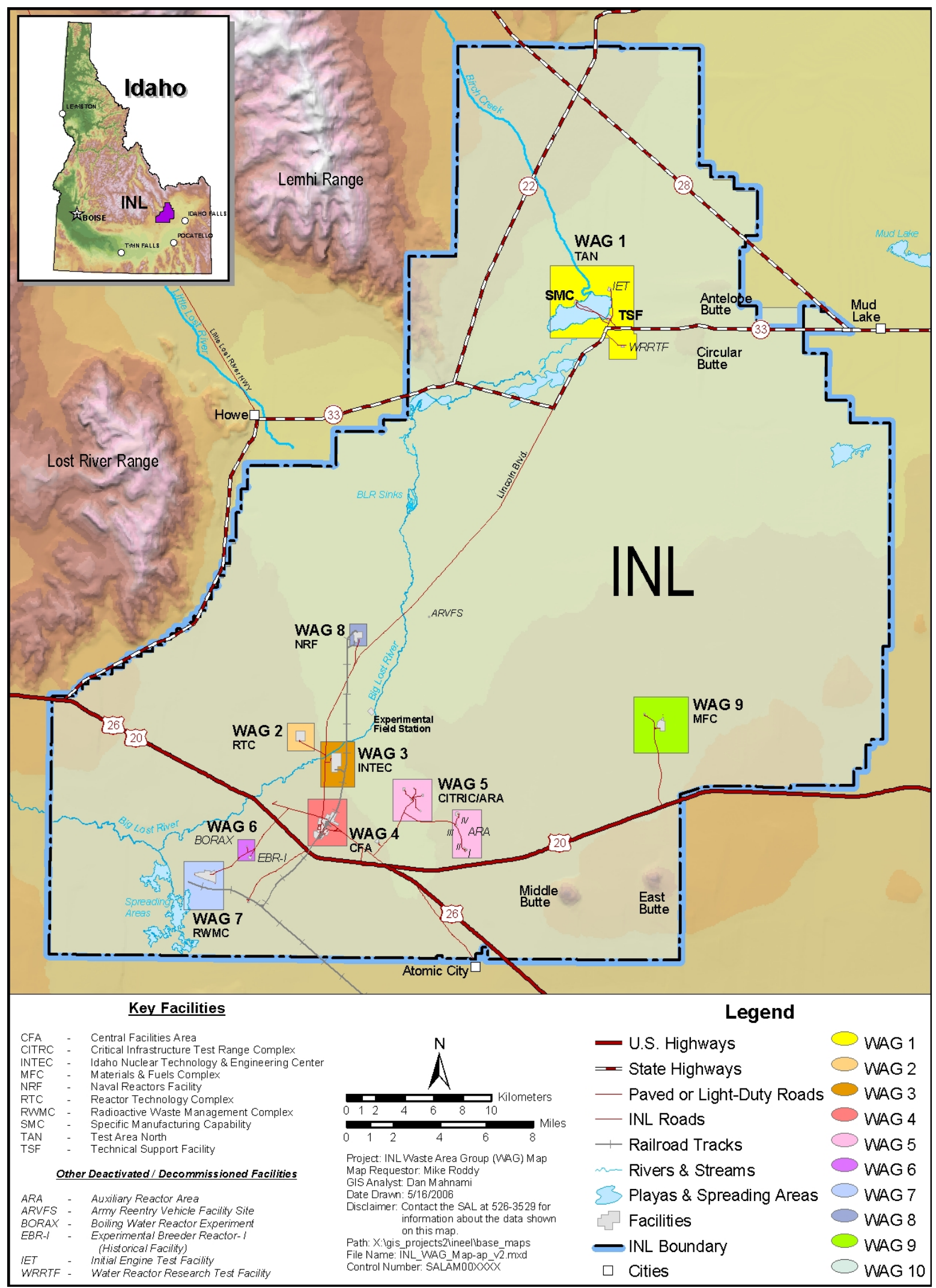

Figure 1-1. Idaho National Laboratory site map showing Waste Area Group locations. 
beneath the INL Site is critical for communicating INL impacts to other SRPA water users. Another critical purpose of OU 10-08 groundwater monitoring is to collect tangible evidence that water contaminated above maximum contaminant levels (MCLs) or risk-based levels does not extend beyond the downgradient boundaries of INL.

Development of this plan was based on the initial 4 years of sampling and the data gaps/data needs identified in the Waste Area Group 10, Operable Unit 10-08, Remedial Investigation/Feasibility Study Work Plan (FINAL) (DOE-ID 2002a). The data gaps identified in the OU 10-08 RI/FS Work Plan (DOE-ID 2002a) include the lack of consistent or accurate groundwater elevation measurements, lack of consistent analytical groundwater data collected at the scale of the INL, and new wells needed to address monitoring requirements in unmonitored locations. The installation of new monitoring wells is covered in another plan (the Operable Unit 10-08 Prioritization of Drilling Locations for Fiscal Year 2005 and Outyears [ICP 2005]). The data collected under this groundwater monitoring plan will characterize and assess groundwater risks and will ultimately be used in the OU 10-08 ROD. The scope of this plan is as follows:

1. Collect data to fill data gaps in existing knowledge needed to design, develop, and calibrate the OU 10-08 groundwater model

2. Collect data adequate to assess the risk to human health and the environment from groundwater contamination at the INL for the OU 10-08 RI/FS and subsequently the OU 10-08 ROD

3. Collect data sufficient to demonstrate that groundwater contamination does not extend at significant levels beyond the downgradient boundaries of the INL.

Groundwater monitoring for OU 10-08, as described in this plan, is designed to (a) support the data needs for the OU 10-08 RI/FS and (b) support the transition of groundwater monitoring responsibilities into WAG 10. Water quality data are needed for the OU 10-08 RI/FS for the following purposes:

- $\quad$ Supporting the aquifer model calibration

- $\quad$ Determining whether mixing of plumes from individual WAGs can create a cumulative risk not addressed by individual WAGs

- $\quad$ Corroborating WAG-specific groundwater monitoring.

Note that groundwater monitoring performed under this plan will not duplicate monitoring performed by other WAGs. The Quality Assurance Project Plan (QAPjP) (DOE-ID 2006a) describes the processes and programs that ensure generated data will be suitable for their intended use.

As the INL CERCLA projects move toward completion, long-term monitoring activities will be performed under WAG 10. Sitewide institutional controls and the comprehensive five-year CERCLA reviews have already been consolidated. To support CERCLA compliance monitoring at the INL, a comprehensive Sitewide (WAG 10) groundwater monitoring plan will be prepared after the OU 10-08 ROD is signed. The comprehensive monitoring plan will encompass all groundwater sampling activities managed by the individual WAGs, and it will supersede and replace all existing groundwater monitoring plans. 


\subsection{Regulatory Background}

On July 14, 1989, the EPA proposed placing the Idaho National Engineering and Environmental Laboratory (INEEL) (now the INL) on the National Priorities List of the "National Oil and Hazardous Substances Pollution Contingency Plan" (40 Code of Federal Regulations [CFR] 300). The EPA Region 10 (with public participation during a 60-day comment period following the proposed listing) issued a final rule on November 21, 1989, that listed the INL on the National Priorities List (54 Federal Register [FR] 48184). The U.S. Department of Energy (DOE) Idaho Operations Office (DOE Idaho) is the lead agency for remedy decisions. The EPA Region 10 and Idaho Department of Environmental Quality (DEQ) approve those decisions.

The FFA/CO (DOE-ID 1991) establishes the procedural framework and schedule for response actions at the INL in accordance with CERCLA, the Resource Conservation and Recovery Act (42 USC $\S 6901$ et seq.), and the Idaho Hazardous Waste Management Act (Idaho Code $\S$ 39-4401 et seq.). The FFA/CO signed by DOE Idaho, EPA Region 10, and the State of Idaho identifies 10 WAGs at the INL Site (Figure 1-1).

The FFA/CO defines WAG 10 as the INL Site boundary or beyond, as necessary, to encompass any real or potential impact from INL activities and any areas within the INL Site not covered by other WAGs (DOE-ID 1991). WAG 10 encompasses a large area, and much of that area is uncontaminated. Additionally, WAG 10 is defined as the INL Site boundary minus WAGs 1 through 5, WAGs 7 through 9, and the Jefferson County landfill. The FFA/CO stated that the WAG 6 Comprehensive RI/FS would be incorporated into the OU 10-04 RI/FS. The OU 10-08 encompasses surface sites currently transferred from other OUs, new sites that may be identified after the OU 10-08 ROD is signed, and INL groundwater for sites with completed RODs. With concurrence from the regulatory Agencies, any new site in a WAG whose ROD has been signed also can be included in OU 10-08. 


\section{SITE DESCRIPTION AND BACKGROUND}

The INL Site is a U.S. government-owned facility managed by the DOE. The INL Site occupies approximately $890 \mathrm{mi}^{2}$ of the northwestern portion of the eastern Snake River Plain in southeast Idaho (Figure 1-1). The eastern boundary of the INL Site is located $32 \mathrm{mi}$ west of Idaho Falls, Idaho. Depth to water varies from approximately $200 \mathrm{ft}$ in the northeast corner of the INL Site to 1,000 $\mathrm{ft}$ in the southeast corner. Water table contours for the SRPA underneath the INL Site are depicted in Figure 2-1. The regional groundwater flow is to the south-southwest. Locally, however, the direction of groundwater flow is affected by recharge from rivers, surface water spreading areas, pumpage, and heterogeneity in the aquifer. Across the southern INL Site, the average gradient of the water table is approximately $5 \mathrm{ft} / \mathrm{mi}$.

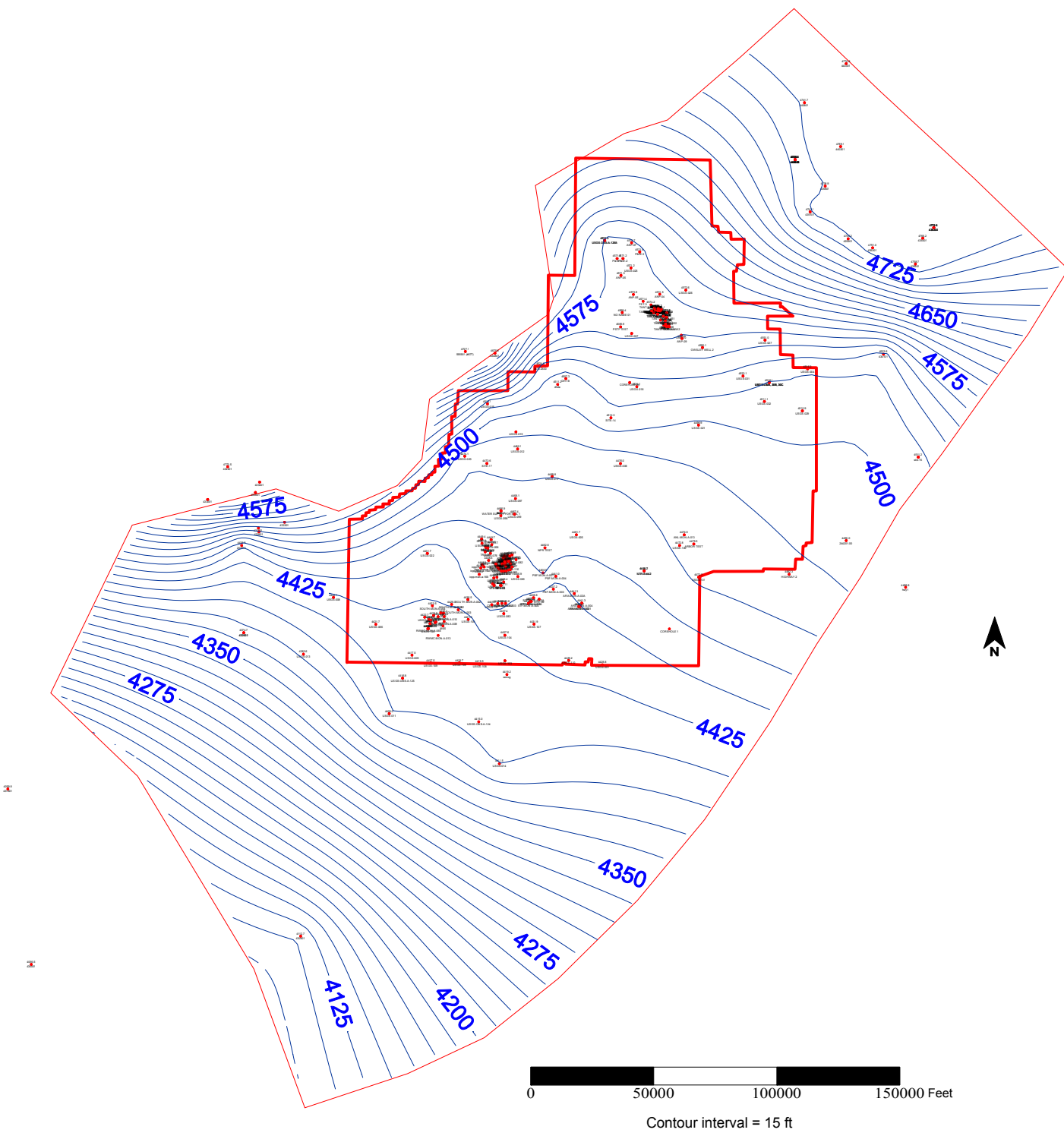

Figure 2-1. Map showing water table contours for the Snake River Plain Aquifer underneath the INL Site. Water table elevation ( $\mathrm{ft}$ ) in blue based on June 2004 data (DOE-ID 2005). Bold red lines show the outline of INL and the boundaries of the map in light red indicate the boundaries of the Operable Unit 10-08 subregional groundwater model. 


\subsection{INL Groundwater Monitoring}

Groundwater contaminant monitoring has been conducted extensively at the INL Site since 1949 by federal and state agencies, universities, and private contractors to evaluate the distribution and transport of contaminants in groundwater. The objective of monitoring is to protect human health and the environment. The DOE has sponsored monitoring activities conducted by the United States Geological Survey (USGS), State of Idaho INL Oversight Program, INL contractors, Idaho State University, and the University of Idaho. INL monitoring networks now include more than 400 wells in the SRPA, vadose zone, and perched groundwater bodies. Analytical results from these wells provide information on the distribution of contaminants in groundwater and document changes in contaminant concentrations in response to natural processes of dispersion, radioactive decay, and biological activity, and to changes that are due to active remediation being performed at INL sites.

Contaminated groundwater at the INL Site has been detected at the Naval Reactors Facility, the Radioactive Waste Management Complex (RWMC), the Reactor Technology Complex (RTC) (formerly known as Test Reactor Area [TRA]), the Central Facilities Area (CFA), the Idaho Nuclear Technology and Engineering Center (INTEC), and Test Area North (TAN) (Figure 1-1). Currently, the Idaho Cleanup Project (ICP) and USGS conduct monitoring to satisfy various WAG-specific program objectives. Some wells are monitored by smaller programs (e.g., Materials and Fuels Complex [formerly Argonne National Laboratory-West]). The wells are monitored as frequently as quarterly, but monitoring frequency ranges to annually, depending on the data needs. A comprehensive Environmental Data Warehouse is operated by the Long-Term Stewardship program to maintain records of all sampling results. Currently, the Sample and Analysis Management (SAM) maintains the groundwater sampling records independently for the ICP and USGS.

\subsection{Previous Operable Unit 10-08 Sampling}

Results of previous groundwater sampling events conducted in support of the WAG $10 \mathrm{RI} / \mathrm{FS}$ are provided in the Fiscal Year (FY) 2003 OU 10-08 RI/FS Annual Report (DOE-ID 2004a), the FY 2003 OU 10-08 RI/FS Supplemental Annual Report (DOE-ID 2004b), the FY 2004 OU 10-08 RI/FS Annual Report (DOE-ID 2005), the FY 2005 Annual Report (DOE-ID 2006b), and the FY 2006 Annual Report ${ }^{\mathrm{a}}$. Groundwater wells sampled under prior OU 10-08 groundwater monitoring plans were routinely sampled for volatile organic compounds (VOCs) (Appendix IX target analyte list), metals (filtered), anions (including bicarbonate), alkalinity, and radionuclides (I-129, tritium, Tc-99, gross alpha, gross beta, gamma spectrometry, uranium isotopes, and Sr-90). The locations of guard, baseline, and boundary wells that were sampled in 2003 and 2004 are shown on Figure 2-2. In 2005, a distal well category was added and USGS-100 was added to the list of guard wells (Figure 2-3). In 2006, The Westbay wells MIDDLE-2050A and MIDDLE-2051 were added and the sampling frequency of the baseline and distal wells reduced (Figure 2-4). Also in FY 2006, the analyte list was reduced with the elimination of gamma spectrometry, uranium isotopes, and bicarbonate. The four well categories were selected to (a) monitor contaminants coming onto the INL Site (baseline), (b) provide early warning downgradient from facilities (guard), (c) monitor contaminants leaving the INL Site (boundary), and (d) monitor wells downgradient of the INL Site (distal). The wells sampled for WAG 10 include wells that are not normally sampled under the other WAGs.

a. DOE-ID, 2007, "Waste Area Group 10, Operable Unit 10-08, Remedial Investigation/Feasibility Study Annual Status Report for Fiscal Year 2006,” DOE/ID-11297, Rev. 0 Draft, U.S. Department of Energy Idaho Operations Office, April 2007. 


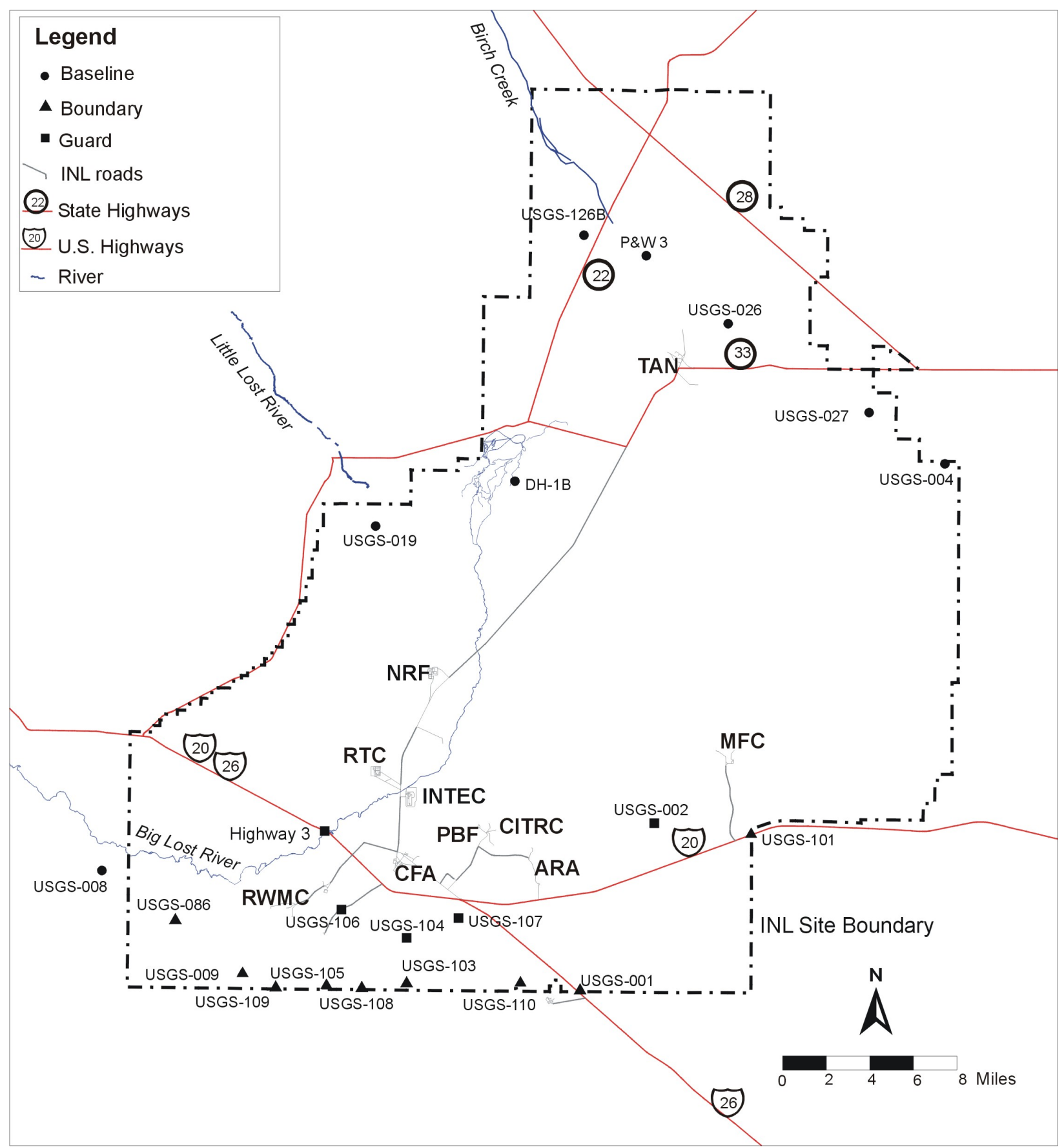

Figure 2-2. Map showing the locations of baseline, boundary, and guard wells sampled at the INL Site in 2003 and 2004. 


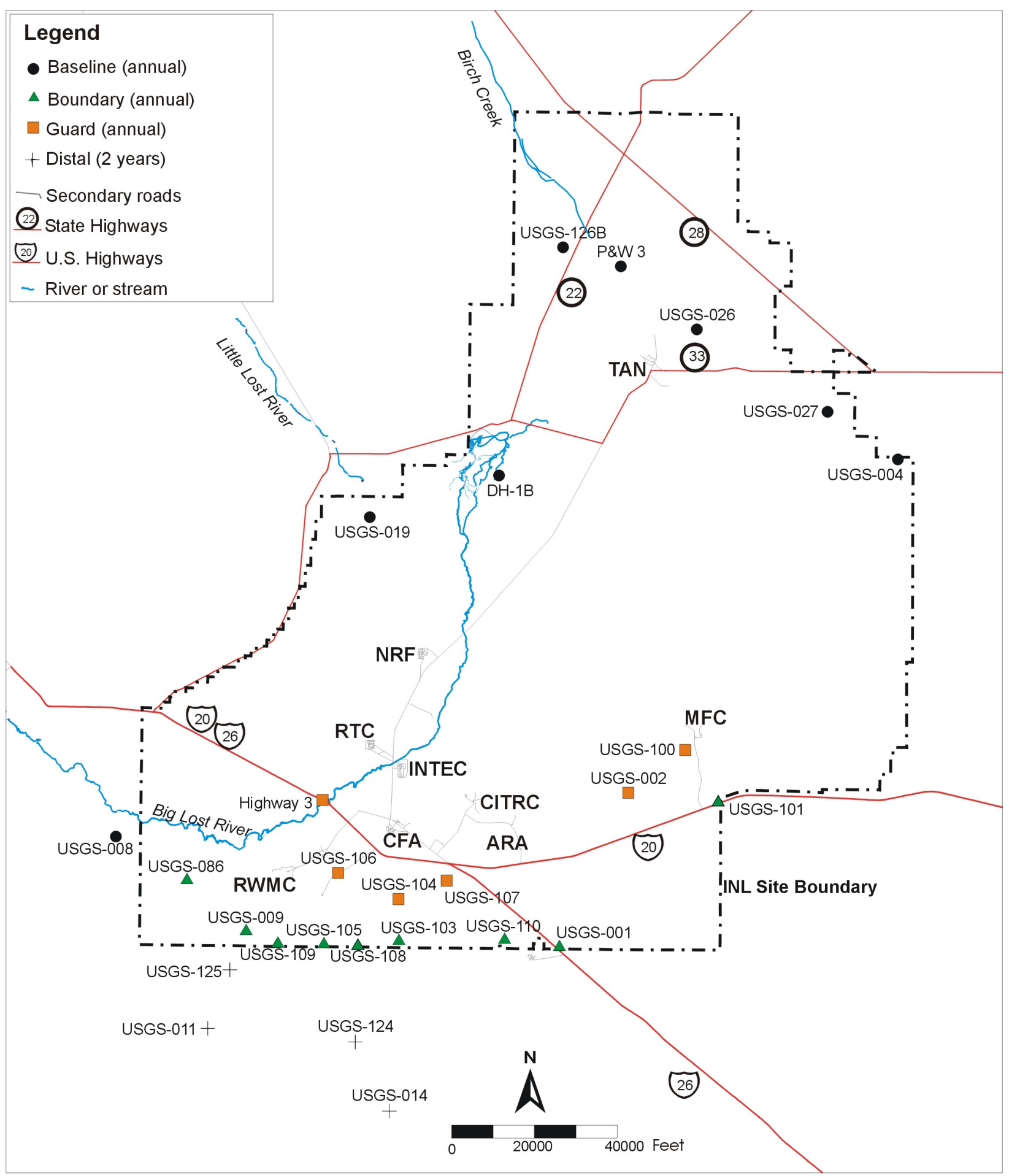

Figure 2-3. Map showing the locations of baseline, boundary, guard, and distal wells sampled at the INL Site in 2005. 


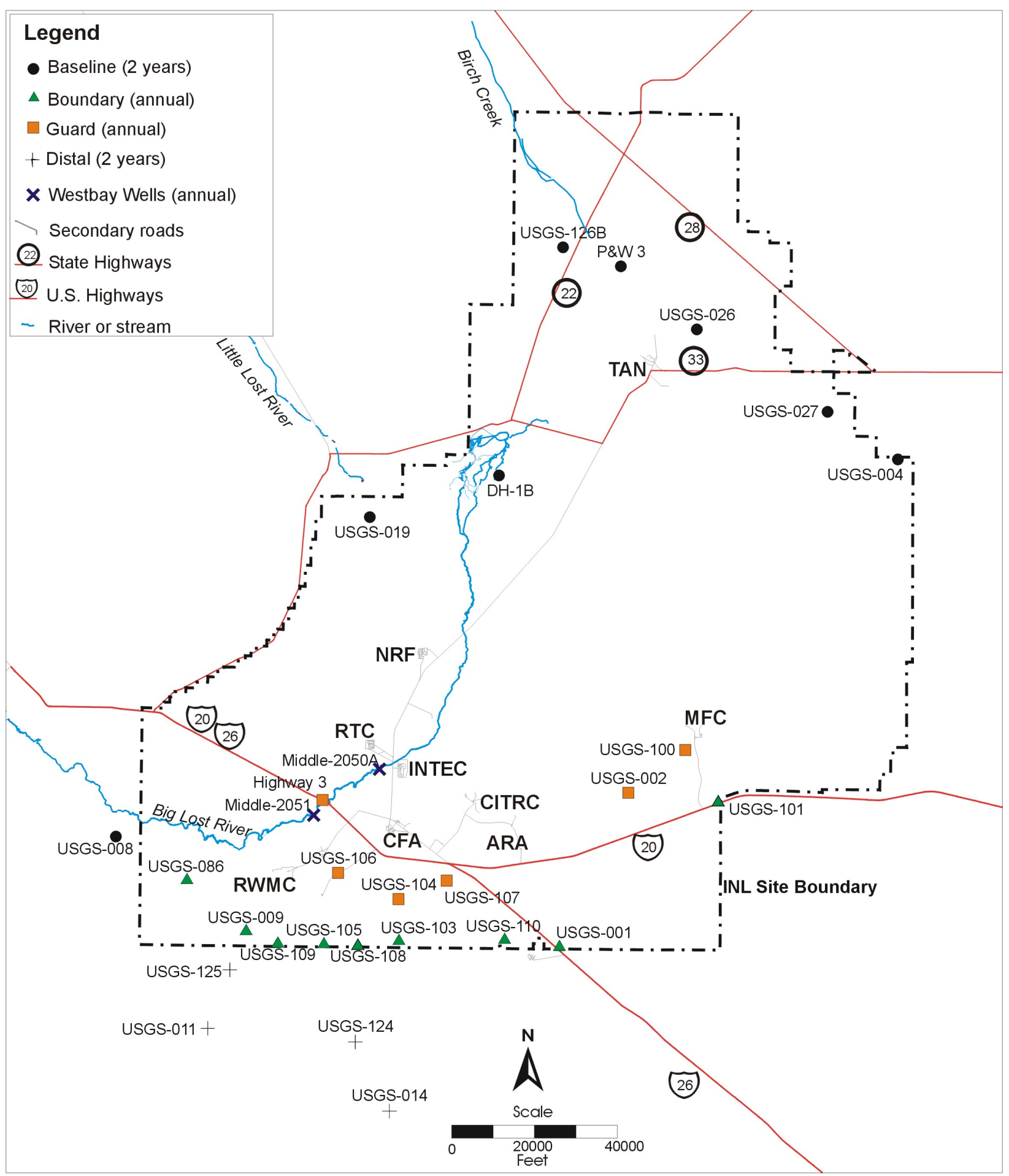

Figure 2-4. Map showing the locations of baseline, boundary, guard, and distal wells sampled at the INL Site in 2006. 
Three water quality sampling events were performed in FY 2003. A sampling event was performed annually in FY 2004, FY 2005, and FY 2006. Two sampling events in FY 2003 - during November 2002 and June 2003 - were conducted on the standard suite of guard, baseline, and boundary wells identified in the OU 10-08 RI/FS Work Plan. In addition to wells sampled during the two standard sampling events, nine wells were sampled for explosives in March 2003 and the Highway 3 well was sampled for nitroaromatics in June 2003 in order to satisfy the requirements of the OU 10-04 ROD associated with potential contamination in the SRPA (DOE-ID 2002b). In addition to the regular suite of analytes, Wells USGS-009, -086, -105, and -109 were sampled for C-14 in June and July of 2003. During June and July of 2004 and 2005, routine groundwater sampling was conducted for the standard suite of guard, baseline, and boundary wells. In 2005, four distal wells south of the INL Site boundary also were sampled.

\subsubsection{Data Summary for Previous OU 10-08 Sampling Events}

The concentrations of gross alpha, gross beta, and uranium isotopes in the suite of guard, baseline, and boundary wells are similar to background values (Knobel, Orr, and Cecil 1992; USGS 1999). Tritium has been detected consistently in two wells, USGS-104 and -106, at concentrations currently near $1,000 \mathrm{pCi} / \mathrm{L}$, which is well below the MCL of $20,000 \mathrm{pCi} / \mathrm{L}$. Currently, both wells exhibit a downward trend in tritium concentration.

VOCs have been detected at low concentrations and well below MCLs in FY 2003, FY 2004, FY 2005, and FY 2006 sampling events (DOE-ID 2004a, 2005, 2006b, and [2007] footnote a). The detections of VOCs have been inconsistent and in most cases can be attributed to laboratory contamination.

Review of the 2003 sampling results from the WAG 10 boundary, baseline, and guard wells indicates that all metals - except thallium - and anions are below their respective MCLs or secondary MCLs. Thallium was reported at concentrations above its MCL in two wells, but when analyzed at a lower detection limit, thallium was not detected in these wells. Zinc concentrations in the groundwater samples from USGS-009, -086, -103, -104, -105, -106, -108, -109, and the Highway 3 well were elevated. The elevated zinc concentrations in these groundwater monitoring wells are the result of corroding galvanized discharge/riser pipe used in their construction (ICP 2004a, 2004b).

The major anion and cation chemistry of baseline wells USGS-004 and -027 suggests off-Site influences. Well USGS-004 has a much higher nitrate concentration than other wells monitored for WAG 10, and this concentration is greater than the USGS background range for the INL Site (DOE-ID 2004b). The higher nitrate concentration in this well reflects an off-Site agricultural influence. In addition, USGS-004 shows an influence of infiltration from Mud Lake, based on oxygen isotope ratios that are indicative of evaporative effects (USGS 1999). The composition of USGS-027 is high in sodium and chloride compared to the other WAG 10 wells and background values for the SRPA. Wells USGS-004 and -027 also have higher conductivity values than the other wells, suggesting an off-Site influence. In the vicinity of USGS-004 and -027, groundwater gradients are south to southwest based on data in the FY 2003, FY 2004, and FY 2005 Annual WAG 10 RI/FS Reports (DOE-ID 2004a, 2005, and 2006b). Considering that the locations of these wells are on or near the INL boundary, this data indicates that the groundwater in these wells is influenced by off-Site sources.

\subsubsection{Data Summary for Explosive Sampling Events}

Historical land uses at the INL Site include munitions and explosives testing. Potential contamination of the soil and groundwater due to the chemical compounds used in these explosives led to the March 2003 OU 10-08 sampling event and the additional sampling of the Highway 3 well in 
June 2004. Sampling was conducted in wells proximal to potential explosive contamination sources. The wells were sampled for trinitrotoluene (TNT), cyclotrimethylene trinitroamine (Royal Demolition Explosive [RDX]), 1,3,5-trinitrobenzene, 4-amino-2, 6-dinitrotoluene, 2,4-dinitrotoluene, and 2,6-dinitrotoluene. Analytical results for wells sampled for explosives or nitroaromatics showed that all compounds were below detectable levels in the SRPA.

\subsection{Other Studies Relevant to Operable Unit 10-08}

The USGS has conducted several contaminant-transport studies that have a bearing on OU 10-08 monitoring and groundwater modeling. The primary tracers used for the USGS groundwater flow and contaminant migration studies were Cl-36 and I-129; Tc-99 was used to a lesser extent. These tracersI-129, Cl-36, and Tc-99 - are present in the SRPA as a result of past facility operations and are opportunistic tracers. They were not injected as part of a tracer study. I-129 and Cl-36 are excellent tracers for groundwater flow and contaminant migration paths. Cl-36 is an excellent tracer, because it is a conservative anion, and I-129 is an excellent tracer in anion form. In addition, I-129 and Cl-36 were selected based on their ability to distinguish sources and to be tracked over great distances. Samples collected for the I-129 and Cl-36 studies were analyzed using the low-detection limit accelerator mass spectrometry (AMS) method; samples collected for Tc-99 studies were analyzed using the thermal ionization mass-spectrometry method.

In addition to studies within and just south of the INL Site boundary, the USGS has conducted sampling farther south - in the Magic Valley area - to evaluate potential impacts from INL activities. The USGS sampling from the southern boundary of the INL Site to the Hagerman area (Magic Valley) was conducted from 1989 to 2003. In the initial sampling in 1989, samples were collected from 55 sites. Subsequent annual sampling was performed at approximately one-third of the wells, so that all of the original sites were sampled every 3 years.

\subsubsection{USGS Studies of Contaminant Migration}

A Cl-36 plume extending from INTEC and RTC to the southern INL Site boundary is described in two studies (Beasley et al. 1993; Cecil et al. 2000). A comparison of tritium and Cl-36 data indicated that the $\mathrm{Cl}-36$ plume extended beyond the area of the tritium plume defined by the $500-\mathrm{pCi} / \mathrm{L}$ concentration for tritium. Cl-36 also was detected in a well at the RWMC (Beasley et al. 1993). Based on the first detection of Cl-36 in USGS-011 and -014 (see Figure 4-1) as early as 1977, contaminant/groundwater flow velocities of approximately $3 \mathrm{ft} /$ day were estimated (Cecil et al. 2000).

Sampling in 1991 and 1992 identified an I-129 plume extending from INTEC to beyond the southern INL Site boundary (Mann and Beasley 1994). It should be noted that the I-129 concentrations south of the INL Site boundary are low (at least two orders of magnitude below the MCL of $1 \mathrm{pCi} / \mathrm{L}$ ). Groundwater flow velocity from INTEC past the southern boundary of the INL Site was estimated at $6 \mathrm{ft} /$ day based on movement of I-129. I-129 also was detected at low concentrations in USGS-90, which is located near the RWMC (Mann and Beasley 1994). The occurrence of a low I-129 concentration near the RWMC suggests that a groundwater flow path from INTEC exists and that INTEC/RWMC plumes could be commingling. The interpretation of flow paths is complicated, because I-129 also is present in the wastes emplaced in the RWMC. Sampling of Magic Valley wells and springs south of the INL Site from 1992 to 1994 indicated background I-129 concentrations (Cecil, Hall, and Green 2003). Although a Cl-36 plume originates from both RTC and INTEC, I-129 appears to originate from INTEC but not from RTC (Mann and Beasley 1994). In addition to samples collected during the Mann and Beasley study, I-129 samples were collected south of INTEC in 1977, 1981, 1986, and 1990. 
Sampling and analysis for Tc-99 using the low-detection limit thermal ionization mass-spectrometry method indicated a plume from INTEC extending past the southern boundary of the INL Site (Beasley, Dixon, and Mann 1998). Tc-99 was detected in the RWMC production well, which is consistent with the low-detection limit I-129 data. This detection suggests that a groundwater flow path extends from INTEC to the RWMC and that commingling of INTEC and RWMC contaminant plumes is possible. However, the interpretation of flow paths is complicated, because Tc-99 is also present in the wastes emplaced in the RWMC. This plan proposes additional sampling to investigate that possibility.

In addition to the radiological analytes discussed above, the USGS has mapped concentrations of chlorofluorocarbons (CFCs) in the SRPA (Busenberg, Plummer, and Bartholomay 2001). The CFC analyses were performed to estimate the age of groundwater beneath the INL Site, but they indicated the presence of several CFC anomalies that could be used as groundwater flow tracers. The CFC study indicated a plume of dichlorodifluoromethane (F-12) originating from INTEC and a 1,1,2-trichloro-1,2,2trifluoroethane (F-113) plume originating at the RWMC. However, the CFC concentrations were very low and required a special analytical method (Busenberg, Plummer, and Bartholomay 2001).

\subsubsection{Magic Valley Sampling}

Evaluation of off-Site impacts is another purpose of WAG 10. The USGS has performed extensive sampling south of the INL Site boundary in the Magic Valley (Twining and Rattray 2003; Bartholomay and Twining 2000; Rattray and Campbell 2003; Bartholomay et al. 2001). When detected, concentrations of radiological analytes, such as tritium, gross alpha, and gross beta, were present at background levels and were below MCLs. Results for organics and inorganics also are reported in the documents referenced above. However, the USGS has discontinued sampling of wells south of the INL Site boundary to the Hagerman area (Magic Valley). The Magic Valley sampling is proposed to be performed by the State of Idaho oversight sampling program. The sampling proposed in Section 4 of this work plan is not part of the program that is to be performed by the State of Idaho oversight sampling program. 


\section{FIELD SAMPLING PLAN OBJECTIVES}

The data quality objective (DQO) summary in Table 3-1 is a modification of the original DQOs presented in the WAG 10 RI/FS Work Plan (DOE-ID 2002a) and the DQOs in the first revision of this plan. The revised DQOs for groundwater monitoring reflect the need to collect data that can be used to (a) calibrate the groundwater flow model, (b) ascertain the potential for plumes to commingle,

(c) determine the vertical distribution of contaminants, and (d) calibrate the groundwater transport model.

The EPA developed the DQO process as a means to "improve the effectiveness, efficiency, and defensibility of decisions" used in the development of data collection designs (EPA 2000). The DQO process is a systematic procedure for defining data collection criteria based on the scientific method. This process consists of seven iterative steps that yield a set of principal study questions (PSQs) and decision statements that must be answered to address a primary problem statement. The seven steps of the DQO process are as follows:

- Step 1: State the problem

- Step 2: Identify the principal study questions

- Step 3: Identify the inputs to the decision

- $\quad$ Step 4: Define the study boundaries

- $\quad$ Step 5: Develop decision rules (DRs)

- Step 6: Specify tolerable limits on the decision

- $\quad$ Step 7: Optimize the design for obtaining data.

The DQOs for groundwater monitoring associated with OU 10-08 are shown in Table 3-1. 


$$
\text { 3-2 }
$$


Table 3-1. Data quality objectives for groundwater monitoring associated with Operable Unit 10-08 groundwater monitoring

\begin{tabular}{|c|c|c|c|}
\hline 1. Problem Statement: & 2. Principal Study Questions: & 3. Inputs to the Decision: & 4. Define the Study Boundaries: \\
\hline \multirow[t]{3}{*}{$\begin{array}{l}\text { 1. What data are required to assess current } \\
\text { conditions and future changes in the nature } \\
\text { and extent of contamination plumes at the } \\
\text { downgradient INL Site boundary? }\end{array}$} & $\begin{array}{l}\text { PSQ-1a. Are the downgradient nature and } \\
\text { extent of all contaminant plumes within } \\
\text { OU 10-08 defined? Do plumes commingle? }\end{array}$ & $\begin{array}{l}\text { The following are inputs to PSQ-1a: } \\
\text { Results from Site monitoring activities performed under OU 10-08 and the other WAGs } \\
\text { Revision of the OU 10-08 groundwater numerical model, incorporating updated Site } \\
\text { concentual model information }\end{array}$ & \multirow{4}{*}{$\begin{array}{l}\text { This study focuses on the transport of COPCS in the groundwater from facilities within the INL Site to its } \\
\text { boundary and beyond. WAG } 10 \text { includes all areas within the INL Site that are not included in the routine } \\
\text { sampling programs for the other WAGs (principally WAGs } 1,2,3,4 \text {, and } 7 \text { ) (Figure } 1-1) \text {. However, the } \\
\text { groundwater modeling also will make use of data collected by the individual WAGs. } \\
\text { This plan will be in effect until the OU } 10-08 \text { ROD is signed. It is understood that a long-term monitoring } \\
\text { plan will be developed and implemented as part of the OU } 10-08 \text { ROD. }\end{array}$} \\
\hline & & $\begin{array}{l}\text { A geochemical study of known contaminant sources using anthropogenic contaminants } \\
\text { and stable isotopes to help identify groundwater flow and contaminant migration } \\
\text { pathways. }\end{array}$ & \\
\hline & $\begin{array}{l}\text { PSQ- } 1 \text { b. Are groundwater and contaminant } \\
\text { flow paths understood and identified? }\end{array}$ & $\begin{array}{l}\text { The following are inputs to PSQ-1b: } \\
\text { Groundwater contaminant data collected by WAG } 10 \text { and other WAGs } \\
\text { Measurement of water levels in monitoring wells installed in the SRPA } \\
\text { Geochemical studies to identify flow paths } \\
\text { Geochemical or biological reactions along flow paths that can attenuate or degrade } \\
\text { contaminant levels. }\end{array}$ & \\
\hline $\begin{array}{l}\text { 2. Will concentrations of selected COPCs } \\
\text { meet regulatory standards (MCLs) or other } \\
\text { applicable risk-based concentrations at all } \\
\text { locations within the INL Site by 2095? }\end{array}$ & $\begin{array}{l}\text { PSQ-2. Are groundwater contaminant } \\
\text { concentrations within the INL Site projected } \\
\text { to comply with MCLs or other acceptable } \\
\text { risk-based concentrations in } 100 \text { years? }\end{array}$ & $\begin{array}{l}\text { The inputs to PSQ-2 may include the following: } \\
\text { Inputs established under PSQ-1a and 1b, above } \\
\text { Model prediction of COPC concentrations in the SRPA through } 2095 \text { and beyond } \\
\text { Risk scenarios. }\end{array}$ & \\
\hline
\end{tabular}

\begin{tabular}{|c|c|c|}
\hline 5. Develop a Decision Rule: & $\begin{array}{l}\text { 6. Specify Tolerable Limits on } \\
\text { Decision Errors: }\end{array}$ & 7. Optimize the Design: \\
\hline \multirow{4}{*}{$\begin{array}{l}\text { DR-1a. If the groundwater sampling data } \\
\text { and the updated Sitewide } \\
\text { conceptual/numerical model indicate that } \\
\text { concentrations of COPCs in the SRPA will } \\
\text { be less than applicable MCLs or regulatory } \\
\text { guides in } 2095 \text { and beyond, then we can } \\
\text { conclude that additional remedial measures } \\
\text { are not needed. }\end{array}$} & \multirow{7}{*}{$\begin{array}{l}\text { The primary remedial action decisions for } \\
\text { OU } 10-08 \text { will be based on results of } \\
\text { numerical modeling that predict groundwater } \\
\text { concentrations in the SRPA in } 2095 \text { and } \\
\text { beyond. As such, the decisions will be based } \\
\text { on estimated values for which specific error } \\
\text { limits cannot be defined in a manner similar to } \\
\text { traditional tolerance limits applied to } \\
\text { laboratory analytical results. The accuracy of } \\
\text { the computer predictions will be evaluated by } \\
\text { comparing model predictions to observed } \\
\text { concentrations. The acceptable degree of } \\
\text { accuracy between the predicted and observed } \\
\text { groundwater concentrations will be agreed } \\
\text { upon with the Agencies. }\end{array}$} & The WAG 10 sampling and monitoring activities will include the following: \\
\hline & & $\begin{array}{l}\text { Yearly sampling of } 15 \text { wells (guard and boundary wells) in FY } 2007 \text { and until the OU 10-08 ROD is signed. The distal wells were sampled in FY 2006, but distal and baseline wells will not be } \\
\text { sampled again prior to finalization of the OU 10-08 ROD. }\end{array}$ \\
\hline & & $\begin{array}{l}\text { Vertical profile packer sampling of Well USGS-105 on the INL boundary in FY } 2006 \text { and FY 2007. Two samples will be collected from this well in FY } 2007 \text { from the same intervals that were } \\
\text { sampled in FY } 2006 .\end{array}$ \\
\hline & & Vertical profile sampling will be performed at the two new wells (MIDDLE-2050A and MIDDLE-2051) with Westbay systems. For FY 2007, the number of intervals sampled in MIDDLE-2050A and \\
\hline \multirow{3}{*}{$\begin{array}{l}\text { DR-1b. If, after } 5 \text { years of monitoring and } \\
\text { incorporation of monitoring data into the } \\
\text { refined OU } 10-08 \text { groundwater model, } \\
\text { concentrations of COPCs in the SRPA are } \\
\text { predicted to be greater than or equal to } \\
\text { applicable MCLs or regulatory guides in } \\
2095 \text { and beyond, then implementation of } \\
\text { additional remedial measures will be } \\
\text { evaluated. }\end{array}$} & & All six ports in the new Westbay well USGS-132 will be sampled in FY 2007 and FY 2008 and pressures will be measured in Westbay well USGS-134 in FY 2007. \\
\hline & & $\begin{array}{l}\text { Data loggers were installed in } 52 \text { wells in FY } 2006 \text { to monitor Big Lost River infiltration and the groundwater gradient across the INL for } 1 \text { year. It is anticipated that the loggers will be removed after } \\
\text { the spring of } 2007 \text { but before the end of FY } 2007 \text {. }\end{array}$ \\
\hline & & A post-ROD long-term monitoring plan will be developed after the OU 10-08 ROD has been signed. The monitoring plan is expected to be revised after the OU 10-08 ROD is finalized. \\
\hline $\begin{array}{l}\text { COPC = contaminant of potential concern } \\
\text { DR = = decision rule } \\
\text { FY = fiscal year } \\
\text { INL = Idaho National Laboratory } \\
\text { MCL = maximum contaminant level } \\
\text { OU = perable entit } \\
\text { PSQ = principal study question } \\
\text { ROD = Record of Decision } \\
\text { SRPA = Snake River Plain Aquifer } \\
\text { WAG = waste area groue }\end{array}$ & & \\
\hline
\end{tabular}





\section{FIELD ACTIVITIES}

This section describes the field activities and procedures to be used to meet the DQOs discussed in Section 3. Before beginning any sampling activities, a pre-job briefing will be held with all worksite personnel to review the requirements of this plan, the Miscellaneous Sites Cleanup Project Health and Safety Plan (HASP) (PLN-2128) and other work control documentation, and to verify that all supporting documentation has been completed. Additionally, a post-job review will be conducted at the end of the sampling and instrument installation activities. The pre- and post-job briefings will be conducted in accordance with applicable procedures. The field team leader (FTL) (and other project personnel) will ensure that the fieldwork is being performed using the most current and applicable procedures.

\subsection{Routine Sampling Locations and Laboratory Analytes}

This sampling plan is for the RI/FS. After the OU 10-08 ROD is signed, however, a comprehensive long-term monitoring plan will be developed.

\subsubsection{Sampling Locations for Fiscal Year 2007}

In a change to the previous OU 10-08 groundwater monitoring plan, the routine OU 10-08 sampling will sample the guard and boundary wells (Figure 4-1). Table 4-1 lists well identifiers, well names, and other information about the wells in the OU 10-08 monitoring network. Downgradient boundary and guard wells will be sampled because they are considered the most important for determining compliance with MCLs and reaching cumulative risk thresholds in the groundwater from INL sources by FY 2095. Baseline wells will not be sampled further prior to the OU 10-08 ROD. Baseline wells are used to monitor upgradient influences. Distal wells also will not be sampled again prior to finalization of the OU 10-08 ROD. These wells are sampled to provide data to demonstrate that groundwater downgradient of the INL boundaries is not contaminated above MCLs or risk-based levels.

Sampling will be conducted at three Westbay locations in FY 2007 and pressures only measured at one location. All six sampling ports in USGS-132 will be sampled in FY 2007. As mentioned in Revision 1 of this monitoring plan, two intervals each from Wells MIDDLE-2050A and MIDDLE-2051 will be sampled in FY 2007. The 474- and 1,212-ft sampling ports from MIDDLE-2050a will be sampled. These intervals were selected because the 474-ft interval might show influence from the RTC, and the 1,212-ft interval had manganese above its secondary MCL. In MIDDLE-2051, the 748- and 1,048-ft sampling ports will be sampled. These ports were selected because the 748 -ft sampling port has shown consistent detections of tritium while the 1,048-ft port has shown inconsistent tritium detections. Only pressure readings will be taken at Well USGS-134. The pressure readings will be used to evaluate vertical gradients. MIDDLE-2050A and MIDDLE-2051 will not be sampled again prior to the OU 10-08 ROD. These wells will not be sampled prior to the ROD because data collected after this FY will not be available for the WAG $10 \mathrm{RI} / \mathrm{FS}$ report.

Packer sampling will be performed at USGS-105 in FY 2007. Previously, USGS-108 was identified for packer sampling, but results from 2006 packer sampling did not indicate significant chemistry changes with depth. In addition, a piece of polyvinyl chloride (PVC) in the well limited the depth to which samples could be collected. Well USGS-105 was retained for packer sampling because results from 2006 showed vertical stratification of chemistry (see footnote a). The intervals to be sampled in FY 2007 in USGS-105 will be the same as those sampled in FY 2006. No further packer samples will be collected prior to the OU 10-08 ROD. The need for additional packer sampling will be evaluated in the post-ROD long-term monitoring plan. 


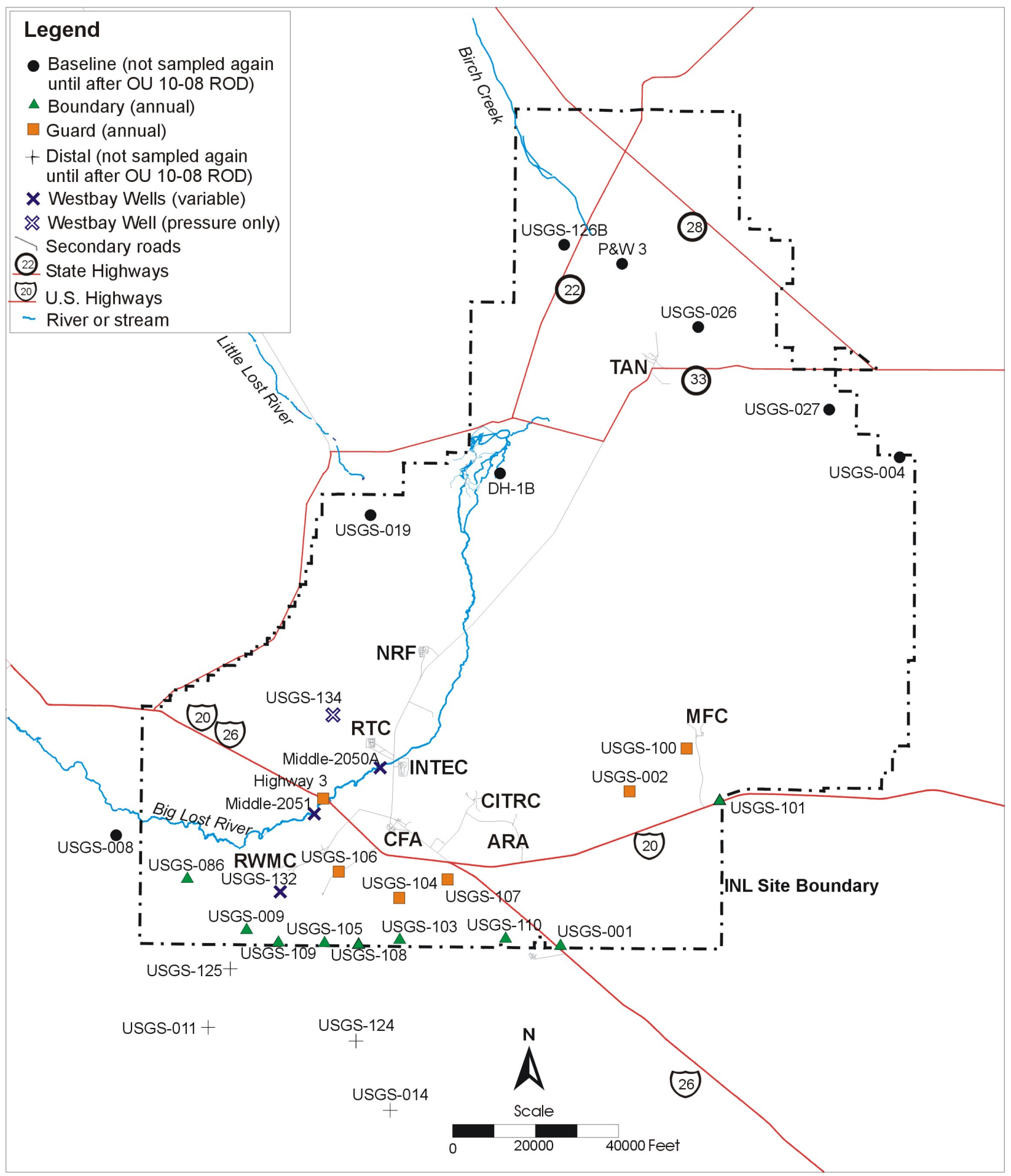

Figure 4-1. Locations and sampling frequency for wells to be sampled for the Operable Unit 10-08 Remedial Investigation/Feasibility Study. 
Table 4-1. Specific well information.

\begin{tabular}{|c|c|c|c|c|}
\hline $\begin{array}{c}\text { Well } \\
\text { Identifier }^{\mathrm{a}} \\
\end{array}$ & Well Name & $\begin{array}{c}\text { Screened or } \\
\text { Open Hole } \\
(\mathrm{ft})\end{array}$ & $\begin{array}{c}\text { Pump Depth } \\
(\mathrm{ft})^{\mathrm{b}}\end{array}$ & $\begin{array}{c}\text { Approximate } \\
\text { Depth to Water } \\
\text { (ft) }\end{array}$ \\
\hline \multicolumn{5}{|c|}{ Boundary Wells } \\
\hline 450 & USGS-001 & 600 to 630 perforated & 612 & 588 \\
\hline 458 & USGS-009 & 620 to 650 perforated & 635 & 607 \\
\hline 535 & USGS-086 & 48 to 691 open hole & 678 & 649 \\
\hline 550 & USGS-101 & 750 to 865 perforated & 790 & 771 \\
\hline 552 & USGS-103 & 575 to 760 open hole & 700 & 583 \\
\hline 554 & USGS-105 & 400 to 800 open hole & 700 & 670 \\
\hline 557 & USGS-108 & 400 to 760 open hole & 637 & 609 \\
\hline 558 & USGS-109 & 600 to 800 open hole & 656 & 621 \\
\hline 559 & USGS-110 & 580 to 780 open hole & 612 & 566 \\
\hline \multicolumn{5}{|c|}{ Guard Wells } \\
\hline 184 & Highway 3 & 680 to 750 perforated & 567 & 538 \\
\hline 451 & USGS-002 & 675 to 696 perforated & 683 & 659 \\
\hline 549 & USGS-100 & 662 to 750 open hole & 703 & 686 \\
\hline 553 & USGS-104 & 550 to 700 open hole & 592 & 555 \\
\hline 555 & USGS-106 & 605 to 760 open hole & 609 & 584 \\
\hline 556 & USGS-107 & 270 to 690 open hole & 531 & 477 \\
\hline \multicolumn{5}{|c|}{ Baseline Wells } \\
\hline 453 & USGS-004 & $\begin{array}{l}285 \text { to } 315 \text { perforated } \\
322 \text { to } 553 \text { open hole }\end{array}$ & 303 & 251 \\
\hline 457 & USGS-008 & 782 to 812 perforated & 801 & 766 \\
\hline 468 & USGS-019 & 289 to 305 perforated & 323 & 276 \\
\hline 475 & USGS-026 & 232 to 266.5 perforated & 255 & 212 \\
\hline 476 & USGS-027 & $\begin{array}{l}250 \text { to } 260 \text { perforated } \\
298 \text { to } 308 \text { perforated }\end{array}$ & 262 & 228 \\
\hline 1346 & USGS-126B & 400 to 452 open hole & 420 & 408 \\
\hline 147 & DH-1B & 380 to 400 open hole & 320 & 268 \\
\hline 250 & $\mathrm{P} \& \mathrm{~W}-3$ & 322 to 401 perforated & 340 & 304 \\
\hline \multicolumn{5}{|c|}{ Distal Wells } \\
\hline 460 & USGS-011 & 672.5 to 703.8 perforated & 687 & $658^{\mathrm{c}}$ \\
\hline 463 & USGS-014 & 720 to 746 perforated & 739 & $720^{\mathrm{c}}$ \\
\hline 987 & USGS-124 & 750 to 800 slotted & Not available & $-^{c}$ \\
\hline 988 & USGS-125 & 620 to 774 slotted & 700 & $634^{\mathrm{c}}$ \\
\hline \multicolumn{5}{|c|}{ Westbay Wells } \\
\hline 2050 & MIDDLE-2050A & Sampling port -474 & Not applicable & Not applicable \\
\hline 2050 & MIDDLE-2050A & Sampling port -647 & Not applicable & Not applicable \\
\hline 2050 & MIDDLE-2050A & Sampling port -790 & Not applicable & Not applicable \\
\hline 2050 & MIDDLE-2050A & Sampling port -1005 & Not applicable & Not applicable \\
\hline
\end{tabular}


Table 4-1. (continued).

\begin{tabular}{|c|c|c|c|c|}
\hline $\begin{array}{c}\text { Well } \\
\text { Identifier }^{\mathrm{a}}\end{array}$ & Well Name & $\begin{array}{l}\text { Screened or } \\
\text { Open Hole } \\
(\mathrm{ft})\end{array}$ & $\begin{array}{l}\text { Pump Depth } \\
(\mathrm{ft})^{\mathrm{b}}\end{array}$ & $\begin{array}{c}\text { Approximate } \\
\text { Depth to Water } \\
\text { (ft) }\end{array}$ \\
\hline 2050 & MIDDLE-2050A & Sampling port - 1212 & Not applicable & Not applicable \\
\hline 2051 & MIDDLE-2051 & Sampling port -608 & Not applicable & Not applicable \\
\hline 2051 & MIDDLE-2051 & Sampling port -748 & Not applicable & Not applicable \\
\hline 2051 & MIDDLE-2051 & Sampling port -834 & Not applicable & Not applicable \\
\hline 2051 & MIDDLE-2051 & Sampling port -1098 & Not applicable & Not applicable \\
\hline 2051 & MIDDLE-2051 & Sampling port -1148 & Not applicable & Not applicable \\
\hline 2029 & USGS-132 & Sampling port -646.7 & Not applicable & Not applicable \\
\hline 2029 & USGS-132 & Sampling port -774.2 & Not applicable & Not applicable \\
\hline 2029 & USGS-132 & Sampling port -836 & Not applicable & Not applicable \\
\hline 2029 & USGS-132 & Sampling port -927.5 & Not applicable & Not applicable \\
\hline 2029 & USGS-132 & Sampling port -1020.5 & Not applicable & Not applicable \\
\hline 2029 & USGS-132 & Sampling port -1182.5 & Not applicable & Not applicable \\
\hline
\end{tabular}

In summary, the activities for FY 2007 are as follows:

- $\quad$ Sample boundary and guard wells

- $\quad$ Packer sampling at USGS-105 - the same two intervals as sampled in 2006

- $\quad$ Sample all six intervals in Westbay well USGS-132

- $\quad$ Sample two intervals in Westbay well MIDDLE-2050A - (474- and 1,212-ft below ground surface [bgs])

- $\quad$ Sample two intervals in Westbay well MIDDLE-2051 - (748- and 1,048-ft bgs)

- $\quad$ Measure pressures in Westbay well USGS-134.

\subsubsection{Sampling Locations for Fiscal Year 2008 and until the OU 10-08 Record of Decision}

Downgradient boundary and guard wells will be sampled annually until the OU 10-08 ROD is signed because they are considered the most important for determining compliance with MCLs. Baseline and distal wells will not be sampled again prior to the OU 10-08 ROD.

In addition to sampling the boundary and guard wells in FY 2008, all intervals from the Westbay well USGS-132 will be sampled in FY 2008. The FY 2008 data from USGS-132 likely will not be available for incorporation into the WAG $10 \mathrm{RI} / \mathrm{FS}$ report, but this data will be used to confirm the FY 2007 data and for determination of wells to be monitored post ROD. 


\subsubsection{Analytes for the OU 10-08 Remedial Investigation/Feasibility Study}

The list of analytes for OU 10-08 monitoring is based on identified contaminants of concern (COCs) in the RODs for individual WAGs (Table 4-2). The COCs are discussed in greater detail in the OU 10-08 RI/FS Work Plan (DOE-ID 2002a). The WAG 10 routine monitoring includes all of the analytes in Table 4-2 except plutonium, Am-241, gamma spectrometry and uranium isotopes.

Both plutonium and Am-241 are monitored near INTEC and the RWMC by WAGs 3 and 7, respectively. Because of the low mobility for plutonium and Am-241, they were not included in the routine OU 10-08 monitoring.

In previous sampling events for WAG 10, gamma spectrometry and uranium isotopes (U-233/234, U-235, and U-238) were included. Gamma spectrometry has been eliminated since the analytes associated with this analysis do not form plumes or have low mobility (such as Cs-137). Uranium isotopes have been eliminated since a uranium plume has not been detected at upgradient facilities and concentrations in previous OU 10-08 samples have been at background levels. A total uranium concentration will be determined in the metals analysis.

Samples will be analyzed for VOCs, metals (filtered), anions (includes chloride, sulfate, bromide, and fluoride), nitrate/nitrite as nitrogen, alkalinity (total as $\mathrm{CaCO}_{3}$ ), tritium, I-129, gross alpha, gross beta, Tc-99, and Sr-90 (Table 4-3). The Contract Laboratory Program VOC list is being analyzed because the VOCs that are COCs at upgradient facilities (e.g., carbon tetrachloride, TCE, and PCE) are included in the Contract Laboratory Program VOC analysis. Detection limits for select analytes and regulatory levels also are shown in Table 4-3.

In FY 2007, the I-129 analysis for all the sampling intervals from the new Westbay well USGS-132 will use the low-detection limit AMS method used by the Purdue Rare Isotope Measurement Laboratory at Purdue University. The I-129 samples from USGS-132 are being analyzed using the AMS method because high accuracy and precision data is needed for this location to verify groundwater contaminant transport modeling results. Because the Purdue laboratory is a research laboratory, rather than a commercial laboratory, it will not produce the data package that typically accompanies other data and does not guarantee turnaround times. Consequently, the data will not be validated and might not be received in a timely manner.

\subsubsection{Operable Unit 10-08 Sampling Schedule}

The OU 10-08 routine groundwater monitoring in support of the RI/FS is scheduled for June and July of each year until the OU 10-08 ROD is signed.

\subsection{Sampling Quality Assurance/Quality Control and Performance Evaluation Samples}

Section 6 of this plan and the QAPjP (DOE-ID 2006a) require quality assurance/quality control (QA/QC) samples from the SRPA samples. Laboratories on the ICP Qualified Suppliers List will be used for the analyses of all such samples. The QA/QC samples will be collected at the frequency recommended in the QAPjP. The QA/QC samples for the groundwater sampling will include duplicates and could include rinsate samples. Duplicate samples will be collected at a frequency of 1 per 20 samples.

Performance evaluation (PE) samples may be sent to the laboratory(ies) during the sampling event. The PE samples might be spiked with a single analyte or multiple analytes. The need for the PE samples will be evaluated before each sampling event. 
Table 4-2. Groundwater contaminants of concern identified in existing Records of Decision at the INL Site.

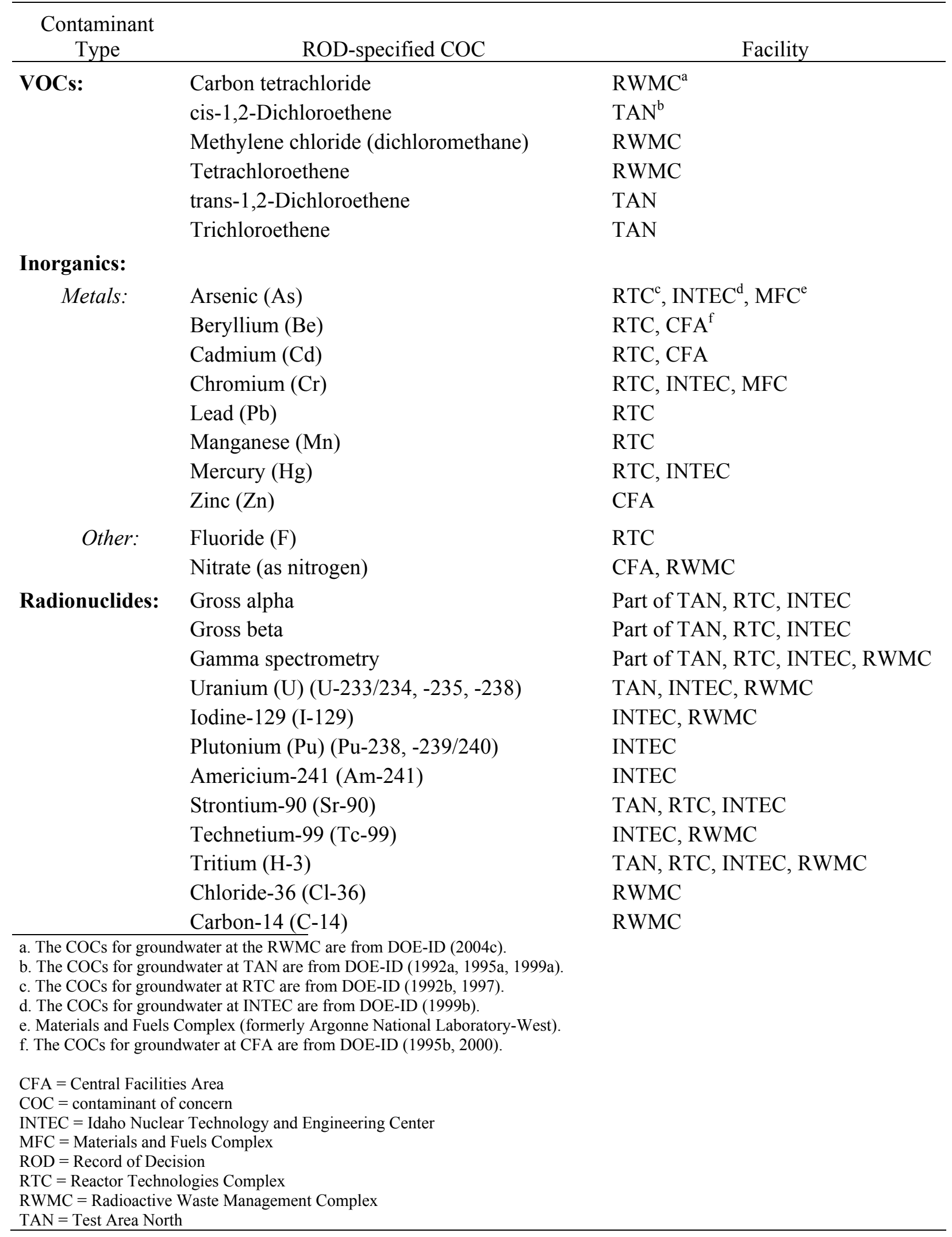


Table 4-3. Operable Unit 10-08 analytes and required quantitation levels.

\begin{tabular}{|c|c|c|c|}
\hline Contaminant Type & Contaminant Name & $\begin{array}{l}\text { Action Level } \\
\text { or MCLs }\end{array}$ & $\begin{array}{l}\text { Practical Quantitation } \\
\text { Limit or Level } \\
\text { Required } \\
\text { (at least half MCL) }\end{array}$ \\
\hline \multirow[t]{6}{*}{ VOCs } & Carbon tetrachloride & $0.005 \mathrm{mg} / \mathrm{L}$ & $0.001 \mathrm{mg} / \mathrm{L}^{\mathrm{a}}$ \\
\hline & cis-1,2-Dichloroethene & $0.07 \mathrm{mg} / \mathrm{L}$ & $0.001 \mathrm{mg} / \mathrm{L}^{\mathrm{a}}$ \\
\hline & Methylene chloride & $0.005 \mathrm{mg} / \mathrm{L}$ & $0.001 \mathrm{mg} / \mathrm{L}^{\mathrm{a}}$ \\
\hline & Tetrachloroethene & $0.005 \mathrm{mg} / \mathrm{L}$ & $0.001 \mathrm{mg} / \mathrm{L}^{\mathrm{a}}$ \\
\hline & trans-1,2-Dichloroethene & $0.1 \mathrm{mg} / \mathrm{L}$ & $0.001 \mathrm{mg} / \mathrm{L}^{\mathrm{a}}$ \\
\hline & Trichloroethene & $0.005 \mathrm{mg} / \mathrm{L}$ & $0.001 \mathrm{mg} / \mathrm{L}^{\mathrm{a}}$ \\
\hline \multirow{7}{*}{$\begin{array}{l}\text { Inorganics } \\
\text { (Contract Laboratory } \\
\text { Program metals plus } \\
\text { uranium, and strontium) }\end{array}$} & Arsenic & $0.05 \mathrm{mg} / \mathrm{L}$ & $0.005 \mathrm{mg} / \mathrm{L}$ \\
\hline & Beryllium & $0.004 \mathrm{mg} / \mathrm{L}$ & $0.001 \mathrm{mg} / \mathrm{L}$ \\
\hline & Cadmium & $0.005 \mathrm{mg} / \mathrm{L}$ & $0.001 \mathrm{mg} / \mathrm{L}$ \\
\hline & Chromium & $0.1 \mathrm{mg} / \mathrm{L}$ (total) & $0.002 \mathrm{mg} / \mathrm{L}$ \\
\hline & Lead & $0.015 \mathrm{mg} / \mathrm{L}$ & $0.002 \mathrm{mg} / \mathrm{L}$ \\
\hline & Mercury & $0.002 \mathrm{mg} / \mathrm{L}$ & $0.0001 \mathrm{mg} / \mathrm{L}$ \\
\hline & Zinc & $5 \mathrm{mg} / \mathrm{L}$ (SDWS [5]) & $0.020 \mathrm{mg} / \mathrm{L}$ \\
\hline \multirow[t]{5}{*}{ Anions } & Nitrate (as nitrogen) & $10 \mathrm{mg} / \mathrm{L}$ & $0.5 \mathrm{mg} / \mathrm{L}$ \\
\hline & Chloride & 250 mg/L (SDWS [5]) & $0.5 \mathrm{mg} / \mathrm{L}$ \\
\hline & Alkalinity (total) & Not applicable & $10 \mathrm{mg} / \mathrm{L}$ \\
\hline & Fluoride & $\begin{array}{l}4.0 \mathrm{mg} / \mathrm{L} \\
(2.0 \mathrm{mg} / \mathrm{L} \text { SDWS [5]) }\end{array}$ & $0.5 \mathrm{mg} / \mathrm{L}$ \\
\hline & Sulfate & $250 \mathrm{mg} / \mathrm{L}$ (SDWS [5]) & $1 \mathrm{mg} / \mathrm{L}$ \\
\hline \multirow[t]{6}{*}{ Radionuclides } & Gross alpha & $15 \mathrm{pCi} / \mathrm{L}$ (total) & $2 \mathrm{pCi} / \mathrm{L}$ \\
\hline & Gross beta (manmade) & $\begin{array}{c}\text { Not to exceed } \\
4 \mathrm{mrem} / \mathrm{year} \text { to the whole } \\
\text { body or any organ }\end{array}$ & $4 \mathrm{pCi} / \mathrm{L}$ \\
\hline & $\mathrm{I}-129$ & $1 \mathrm{pCi} / \mathrm{L}$ & $0.2 \mathrm{pCi} / \mathrm{L}$ \\
\hline & Sr-90 & $8 \mathrm{pCi} / \mathrm{L}$ & $0.5 \mathrm{pCi} / \mathrm{L}$ \\
\hline & Tc-99 & $900 \mathrm{pCi} / \mathrm{L}$ & $10 \mathrm{pCi} / \mathrm{L}$ \\
\hline & $\mathrm{H}-3$ & $20,000 \mathrm{pCi} / \mathrm{L}$ & $400 \mathrm{pCi} / \mathrm{L}$ \\
\hline \multicolumn{4}{|c|}{ a. Based on 25-mL sample volume. } \\
\hline \multicolumn{4}{|c|}{$\begin{array}{l}\mathrm{MCL}=\text { maximum contaminant level } \\
\text { SDWS = secondary drinking water standard } \\
\text { VOC = volatile organic compound }\end{array}$} \\
\hline
\end{tabular}




\subsection{Water Level Measurement Locations and Schedule}

Data loggers were installed in 52 wells to monitor Big Lost River infiltration and the groundwater gradient across the INL for one year (Figure 4-2). Data loggers will be removed in late FY 2007, after any spring flow occurs in the Big Lost River. Water levels will be measured prior to removal of the data loggers with an electronic measuring tape (Solinst ${ }^{\mathbb{B} b}$ brand or equivalent) or a steel tape measure scaled in feet with markings to $0.01 \mathrm{ft}$. Water level measurements will be recorded to the nearest $0.01 \mathrm{ft}$. Water levels will be measured according to the latest ICP procedure.

b. References herein to any specific commercial product, process, or service by trade name, trademark, manufacturer, or otherwise, does not necessarily constitute or imply its endorsement, recommendation, or favoring by the U.S. Government, any agency thereof, or any company affiliated with the Idaho National Laboratory. 


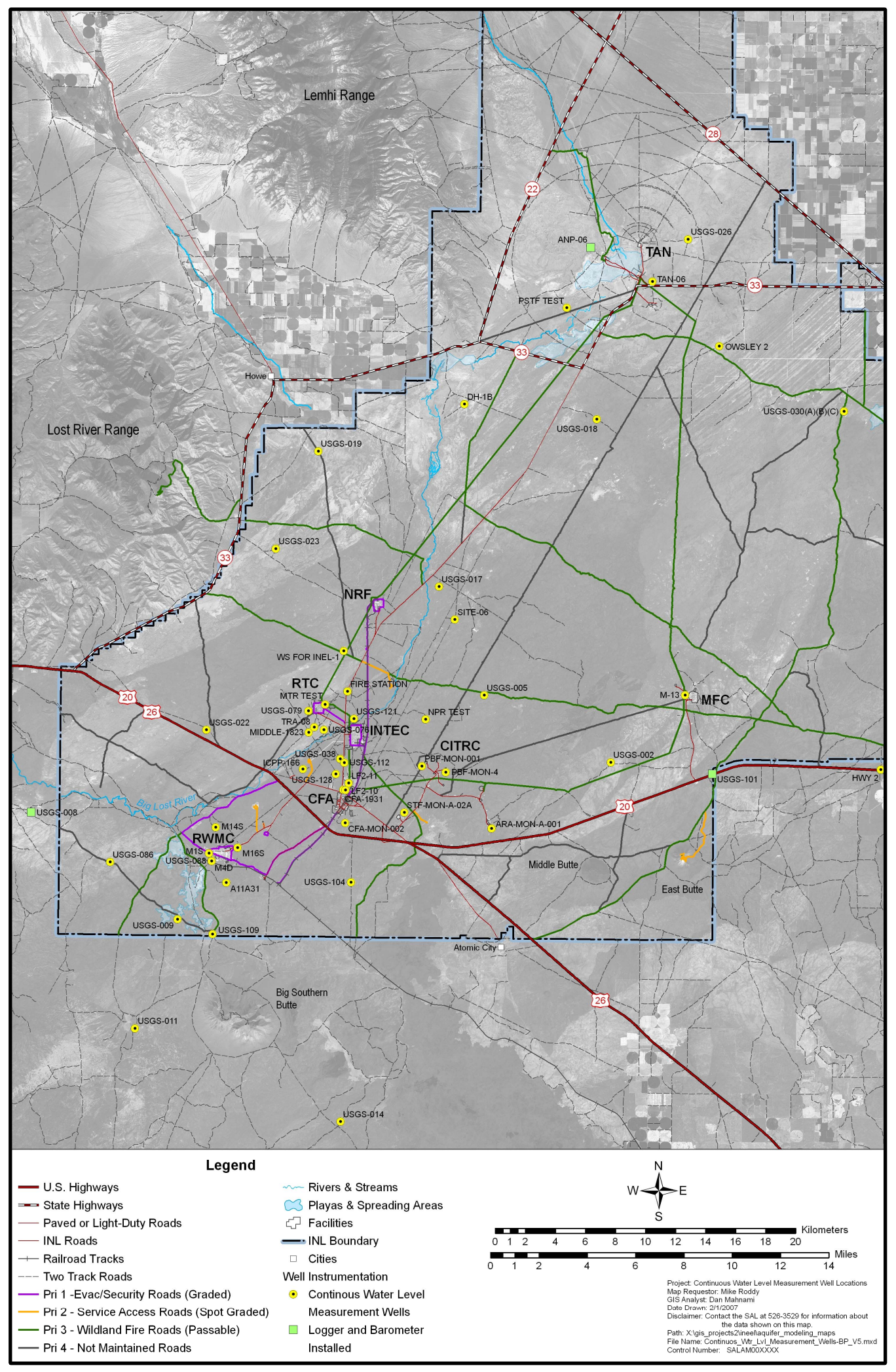

Figure 4-2. Location of wells in automated water-level monitoring network. 


\section{GROUNDWATER SAMPLING PROCEDURES AND EQUIPMENT}

This section describes procedures and the equipment to be used for routine OU 10-08 sampling and monitoring. A pre-sampling meeting will be held before commencement of any sampling activities to review the requirements of this groundwater monitoring plan, any applicable company policies and procedures, the latest revision of the project HASP (PLN-2128), and to ensure that all supporting documentation has been completed. PLN-2128 governs all work that is performed by INL personnel and INL subcontractors or employees of other companies in support of OU 10-08. Figure 4-1 shows the wells to be sampled as part of the routine OU 10-08 sampling.

\subsection{Groundwater Elevations}

Prior to sampling, all groundwater elevations will be measured using either an electronic measuring tape (Solinst ${ }^{\circledR}$ brand or equivalent) or a steel tape measure, as described in the latest ICP standard operating procedure. Measurement of all water levels will be recorded to the nearest $0.01 \mathrm{ft}$.

\subsection{Well Purging}

The Westbay wells will be sampled according to the manufacturer's recommendations, which usually do not include purging. Well purging will follow the latest ICP procedure. All wells that have sufficient water will be purged before sample collection. During the purging operation, a Hydrolab ${ }^{\circledR}$ (or equivalent) will be used to measure specific conductance, $\mathrm{pH}$, and temperature. Samples for water quality analysis can be collected after a minimum of one well casing volume of water has been purged from the well and when three consecutive water quality parameter measurements are within the following limits:

- $\mathrm{pH}+/-0.2$

- $\quad$ Temperature $+/-0.5^{\circ} \mathrm{C}$

- $\quad$ Specific conductance $+/-5 \%$ of value.

If $\mathrm{pH}$, temperature, and specific conductance fail to stabilize within the above limits, purging will continue until three well casing volumes of water have been purged from the well, at which point sampling will commence regardless of stabilization. Some of the wells may have inadequate yields to supply sufficient purge volume. In that case, the well should be purged to dryness and sampled the next working day.

\subsection{Groundwater Sampling}

Prior to sampling, all nondedicated sampling equipment that will come in contact with the water sample will be cleaned using the latest ICP procedure for decontamination of field sampling equipment. After sampling, all nondedicated equipment that came in contact with the well water will be decontaminated before storage, before sampling different depths, and between different groundwater monitoring wells, in accordance with the latest ICP procedure.

Prior to purging, the water level in each well will be measured. The well will then be purged. The Westbay systems will be sampled according to the latest ICP standard operating procedure.

Routine groundwater samples will be analyzed for the analytes listed in Table 4-3. The requirements for containers, preservation methods, sample volumes, holding times, and analytical methods will be in the laboratory statement of work to be prepared before sampling. 
Except for volatile organic analyte vials that must be filled completely, sample bottles will be filled to approximately 90 to $95 \%$ of capacity to allow for content expansion or preservation. Samples to be analyzed for metals will be filtered through a $0.45-\mu \mathrm{m}$ filter in the field prior to acidification. Samples requiring acidification will be acidified to $\mathrm{a} \mathrm{pH}<2$ in the field.

\subsection{Personal Protective Equipment}

The personal protective equipment (PPE) required for this sampling effort is discussed in PLN-2128. Before disposal, all PPE will be characterized for disposal or decontamination based on groundwater and field screening results. A hazardous waste determination for all PPE will be made using applicable company policies and procedures. 


\section{SAMPLE CONTROL}

Strict sample control is required for any project. Sample control ensures that unique sample identifiers are used for separate samples. It also covers the documentation of sample collection information so that a sampling event can be reconstructed at a later date. The following subsections provide details about sample designation, handling, shipping, and radiological screening.

\subsection{Sample Designation}

A systematic code is crucial for the unique identification of samples. Uniqueness is required for maintaining consistency within a project and preventing the same identification code from being assigned to more than one sample.

\subsubsection{Sample Identification Code}

A systematic character identification code will be used to uniquely identify all samples. The first three designators of the code (i.e., GWM) indicate that the sample originated from groundwater monitoring activities. The next three numbers designate the sequential sample number for the project. The seventh and eighth characters represent a two-character set (e.g., 01, 02) for designation of field duplicate samples. The last two characters refer to a particular analysis and bottle type.

For example, a groundwater sample collected in support of the OU 10-08 monitoring might be designated as GWM00101AN, where (from left to right):

- GWM designates the sample as being collected for OU 10-08

- $\quad 001$ designates the sequential sample number

- $\quad 01$ designates the type of sample $(01=$ original, $02=$ field duplicate $)$

- $\quad$ AN designates anion analysis.

A sampling and analysis plan (SAP) table/database will be prepared before sampling and used to record all pertinent information (e.g., well designation, media, and date) associated with each sample identification code.

\subsubsection{Sampling and Analysis Plan Table/Database}

6.1.2.1 General. A SAP table format was developed to simplify the presentation of the sampling scheme for project personnel. The following subsections describe the information recorded in the SAP table/database.

6.1.2.2 Sample Description Fields. The sample description fields contain the following information about individual sample characteristics:

- Sampling Activity - The sampling activity field contains the first six characters of the assigned sample number. The sample number in its entirety will be used to link information from other sources (e.g., field data and analytical data) to the information in the SAP table for data reporting, sample tracking, and completeness reporting. The sample number also will be used by the analytical laboratory to track and report analytical results. 
- Sample Type - Data in this field will be selected from the following:

$$
\begin{array}{lll}
\text { - REG } & \text { for a regular sample } \\
\text { - } & \text { QC } & \text { for a quality control sample. }
\end{array}
$$

- Media - Data in this field will be selected from the following:

$\begin{array}{lll}\text { - } & \text { GROUNDWATER } & \text { for water collected from groundwater } \\ \text { - } & \text { WATER } & \text { for regular and QA/QC samples of groundwater. }\end{array}$

- Collection Type - Data in this field will be selected from the following:

$\begin{array}{lll}\text { - } & \text { GRAB } & \text { for grab samples (undisturbed and disturbed core sample) } \\ \text { - } & \text { FBLK } & \text { for field blanks } \\ \text { - } & \text { RNST } & \text { for rinsates } \\ \text { - } & \text { DUP } & \text { for duplicates } \\ - & \text { TBLK } & \text { for volatile organic analyte trip blanks. }\end{array}$

6.1.2.3 Planned Date. This date is related to the planned sample collection start date.

6.1.2.4 Sample Location Fields. This group of fields pinpoints the exact location for the sample in three-dimensional space, starting with the general area, narrowing the focus to an exact location geographically, and then specifying the depth in the depth field, as follows:

- $\quad$ Area - The area field identifies the general sample collection area. This field should contain the standard identifier for the INL area being sampled. For this investigation, samples are being collected from sites designated as WAG 10 OU 10-08 groundwater. The area field identifier will correspond to this site.

- Location - This field generally contains program-specific information such as the borehole or well identification number but can contain geographical coordinates, $x-y$ coordinates, building numbers, or other location-identifying details. Data in this field normally will be subordinate to the area. This information is included on the labels generated by SAM to aid field sampling personnel.

- Type of Location-This field supplies descriptive information about the exact sample location. Information in this field can overlap with that in the location field, but the information is intended to add detail about the location.

- $\quad$ Depth - The depth of a sample location is the distance in feet from ground surface or a range in feet from the surface.

\subsubsection{Analysis Types}

- $\quad$ AT1-AT20 - These fields indicate analysis types (e.g., radiological and chemical) and the number to be collected for each sample number. Space is provided at the bottom of the form to clearly identify each type. A standard abbreviation also is provided for each analysis below the Analysis Types cell. 


\subsection{Sample Handling}

Samples for laboratory analyses will be collected in pre-cleaned containers and packaged according to American Society for Testing and Materials, or EPA-recommended, procedures. The quality assurance samples will be included to satisfy the QA/QC requirements for the field operation, as outlined in the QAPjP (DOE-ID 2006a). Laboratories on the ICP Qualified Suppliers list will analyze the samples.

\subsubsection{Sample Preservation}

Immediately after collection, all groundwater, rinsate, and QA/QC samples will be placed in coolers containing frozen, reusable ice packs or ice. Samples that require cooling will be maintained at $4^{\circ} \mathrm{C}\left(39^{\circ} \mathrm{F}\right)$ beginning immediately after sample collection, and throughout sample shipment. After preservation, sample coolers will have chain-of-custody $(\mathrm{CoC})$ seals attached.

\subsubsection{Chain-of-Custody Procedures}

The CoC forms will be completed following applicable company procedures and the QAPjP (DOE-ID 2006a). Sample containers will be stored in a secured area accessible only to the field team members.

\subsubsection{Transportation of Samples}

Samples will be shipped in accordance with the regulations issued by the Department of Transportation (DOT) (49 CFR 171 through 178) and EPA sample-handling, -packaging, and -shipping methods (40 CFR 261.3). Samples will be packaged in accordance with the requirements set forth in company policies and procedures.

6.2.3.1 Custody Seals. Custody seals will be placed on all shipping containers in a manner that ensures tampering or unauthorized opening does not compromise sample integrity. Clear plastic tape will be placed over the seals to ensure that they are not damaged during shipment.

6.2.3.2 On- and Off-Site Shipping. An on-Site shipment is any transfer of material within the perimeter of the INL Site. Site-specific requirements for transporting samples within INL Site boundaries and those required by the shipping and receiving department will be followed. Shipment within the INL Site boundaries will conform to DOT requirements as stated in 49 CFR. Off-Site sample shipment will be coordinated with Packaging and Transportation personnel, as necessary, and will conform to all applicable DOT requirements. 


\section{QUALITY ASSURANCE/QUALITY CONTROL}

This section details the field elements of the QAPjP to support field operations during implementation of this field sampling plan (DOE-ID 2006a). The QAPjP pertains to all environmental and radiological testing, analysis, and data review.

\subsection{Project Quality Objectives}

Quality assurance objectives specify the measurements that must be met to produce acceptable data for a project. The technical and statistical qualities of those measurements must be properly documented. Precision, accuracy, and completeness are quantitative parameters that must be specified for physical/chemical measurements. Comparability and representativeness are qualitative parameters.

Quality assurance objectives for this project will be met through a combination of field and laboratory checks. Field checks will consist of collecting field duplicates, equipment blanks, and field blanks. Laboratory checks consist of initial and continuing calibration samples, laboratory control samples, matrix spikes, and matrix spike duplicates. Laboratory quality assurance is detailed in the QAPjP (DOE-ID 2006a) and is beyond the scope of this plan.

\subsubsection{Field Precision}

Field precision is a measure of the variability not attributed to laboratory or analytical methods. The three types of field variability or heterogeneity are spatially within a data population, between individual samples, and within an individual sample. Although the heterogeneity between and within samples can be evaluated using duplicate and/or sample splits, overall field precision will be calculated as the relative percent difference between two measurements or the relative standard deviation between three or more measurements. The relative percent difference or relative standard deviation will be calculated as indicated in the QAPjP (DOE-ID 2006a) for duplicate samples during the data validation process. Precision goals have been established for inorganic Contract Laboratory Program methods by the EPA (EPA 1993) and for radiological analyses in the applicable SAM procedures.

Duplicate samples to assess precision will be collocated and collected by field personnel at a minimum frequency of one duplicate for every 20 samples, with the location of the QA/QC samples being rotated between sampling events.

\subsubsection{Field Accuracy}

Cross contamination of the samples during collection or shipping could yield incorrect analytical results. To assess the occurrence of any cross contamination, equipment blanks and field blanks will be collected. The goal of the sampling program is to eliminate any cross contamination associated with sample collection or shipping. Analytical results for these samples will be evaluated during the data validation process by sample delivery group. If necessary, the data will be blank-qualified to indicate the absence or presence of cross contamination.

Field personnel will collect rinsate, equipment, and field blanks during the course of the project. The rinsate, equipment, and field blanks will be collected at a frequency of one every 20 samples or once for every sample day, whichever is less (DOE-ID 2006a). If activities that could contaminate the samples are identified during sampling, additional blank samples can be collected at the discretion of the FTL. 


\subsubsection{Representativeness}

Representativeness is evaluated by assessing the accuracy and precision of the sampling program and expressing the degree to which samples represent actual site conditions. In essence, representativeness is a qualitative parameter that addresses whether the sampling program was properly designed to meet the DQOs. The representativeness criterion is best satisfied by confirming that a sufficient number of samples are collected to meet the requirements stated in the DQOs. The DQOs are identified in Section 3 of this plan.

\subsubsection{Comparability}

Comparability is a qualitative measure of the confidence with which one data set can be compared to another. These data sets include data generated by different laboratories performing this work, data generated by laboratories in previous studies, data generated by the same laboratory over a period of several years, or data obtained using differing sampling techniques or analytical protocols. For field aspects of this program, data comparability will be achieved using standard methods of sample collection and handling. Procedures identified to standardize the sample collection and handling are included in applicable company policies and procedures.

\subsubsection{Completeness}

Field completeness will be assessed by comparing the number of samples collected to the number of samples planned. Field sampling completeness is affected by such factors as equipment and instrument malfunctions and insufficient sample recovery. Completeness can be assessed after data validation and reduction. The completeness goal for this project is $90 \%$.

\subsection{Data Validation}

All laboratory-generated data, except for low-detection limit I-129 data, will be validated to Level B; however, a Level A data package will be requested from the laboratory. Data will be validated in accordance with company procedures. Field-generated data (e.g., conductivity, temperature, dissolved oxygen, and $\mathrm{pH}$ ) will be validated through the use of properly calibrated instrumentation, comparing and cross checking data with independently gathered data, and recording data-collection activities in a bound field logbook.

\subsection{Quality Assurance Objectives for Measurement}

The quality assurance objectives are specifications that the monitoring and sampling measurements identified in the QAPjP (DOE-ID 2006a) must meet to produce acceptable data for the project. The technical and statistical quality of these measurements must be properly documented. Precision, accuracy, method detection limits, and completeness must be specified for chemical measurements. Quality assurance objectives are specified in the QAPjP (DOE-ID 2006a). 


\section{WASTE MANAGEMENT}

The OU 10-08 project, in coordination with Waste Generator Services (WGS) personnel, will perform the waste determination and determine disposal requirements.

Investigation-derived waste produced during sampling will include spent and unused sample material, PPE, miscellaneous sampling supplies, decontamination water, purge water, and samples. Before sampling begins, WGS will provide a determination for the disposition of all waste, including purge water, based on a waste determination and disposition form. That form describes the required disposal option for purge water. Purge water from most of the wells to be sampled under this plan is anticipated to be eligible for release to the ground surface. Waste generated during sampling activities will be managed in a manner that complies with the established applicable or relevant and appropriate requirements (ARARs), protects human health and the environment, and achieves minimization of remediation waste to the extent possible. The CERCLA waste will be managed in accordance with the following management procedures, as applicable:

- MCP-1390, "Waste Generator Services Waste Management"

- MCP-3475, "Temporary Storage of CERCLA-Generated Waste at the INL Site"

- MCP-1396, "Waste Generator Services Management of CERCLA Waste for Disposal at ICDF." 


\section{DOCUMENT MANAGEMENT}

This section summarizes document-management and sample-control activities that will be performed during this project. Documentation includes $\mathrm{CoC}$ forms, sample container labels, and field logbooks used to record field data and sampling procedures. The analytical results from this field investigation will be documented in reports and used as input for refining the current conditions for the computer model.

\subsection{Documentation}

The FTL will be responsible for controlling and maintaining all field documents and records and for verifying that all required documents submitted to ICP SAM are maintained in good condition. All entries will be made in indelible black ink. Errors will be corrected by drawing a single line through the error and entering the correct information. All corrections will be initialed and dated by the person making the correction.

\subsubsection{Sample Container Labels}

Waterproof, gummed labels generated from the SAP database will display information such as the unique sample identification number, the name of the project, the sample location, and the analysis type. Labels will be completed and placed on the containers in the field before samples are collected. Sample team members will provide information needed to complete the label. Such information may include the date and time the sample was collected, the preservative used, field measurements of hazards, and the sampler's initials.

\subsubsection{Field Guidance Form}

Field guidance forms verifying unique sample numbers provided for each sample location can be generated from the SAP database. These forms contain the following information:

- $\quad$ Media

- $\quad$ Sample identification numbers

- $\quad$ Sample location

- $\quad$ Aliquot identification

- $\quad$ Analysis type

- $\quad$ Container size and type

- $\quad$ Sample preservation.

\subsubsection{Field Logbooks}

Field logbooks will be used to record information necessary to interpret the analytical data. The logbooks will be controlled and managed in accordance with company policies and procedures. 
9.1.3.1 FTL's Daily Logbook. A project logbook maintained by the FTL will contain a daily summary of the following:

- All field team activities necessary to reconstruct the events and methods used to accomplish the objectives of this field sampling plan

- Visitor $\log$ (a site visitor logbook can be assigned to record this information)

- $\quad$ List of site contacts

- $\quad$ Problems encountered

- $\quad$ Corrective actions taken as a result of field audits.

The project logbook will be signed and dated at the end of each day's sampling activities.

9.1.3.2 Sample Logbooks. Sample logbooks will be used by the sample team(s). Each sample logbook will contain information such as

- $\quad$ Physical measurements (i.e. groundwater water-level data, method of water-level measurement; groundwater purge volumes, times, rate of pumping prior to and while sampling groundwater; and the time and value measured for each of the field parameters prior to sample collection)

- $\quad$ Identification of quality control samples

- $\quad$ Sample information (i.e., sample location, sample collection information, analyses requested for each sample, and sample matrix)

- $\quad$ Shipping information (i.e., collection dates, shipping dates, cooler identification number, destination, $\mathrm{CoC}$ number, and name of shipper).

9.1.3.3 Field Instrument Calibration/Standardization Logbook. A logbook containing records of calibration data will be maintained for each piece of equipment that requires periodic calibration or standardization. This logbook will contain logsheets to record the date and time of calibration, the method of calibration, and the instrument identification number.

\subsubsection{Photographs}

No formal photographic records of the activities conducted under this plan are expected to be made. Field personnel can take photographs to record general equipment setups and installation procedures. A minimum of two copies will be made of any photographs taken during this project. One copy will be placed in the project file. The second copy will accompany other project documents (e.g., field logbooks) to be placed in the Document Control and Records Management files.

\subsection{Document Revision Requests}

It might be necessary to revise this document to add or delete wells and analytes, depending on the results and interpretation of data collected under this plan or the results of groundwater monitoring by other WAGs or agencies. Revisions of this document will follow company policies and procedures. Final changes must be approved through the supervising regulatory Agencies, because this is a secondary FFA/CO document. 


\section{REFERENCES}

40 CFR 261.3, 2007, "Definition of Hazardous Waste," Code of Federal Regulations, Office of the Federal Register, April 2007.

40 CFR 300, 2007, "National Oil and Hazardous Substances Pollution Contingency Plan," Code of Federal Regulations, Office of the Federal Register, April 2007.

49 CFR 171, 2007, “General Information, Regulations, and Definitions," Code of Federal Regulations, Office of the Federal Register, February 2007.

49 CFR 172, 2007, "Hazardous Materials Table, Special Provisions, Hazardous Materials Communications, Emergency Response Information, and Training Requirements," Code of Federal Regulations, Office of the Federal Register, February 2007.

49 CFR 173, 2007, "Shippers - General Requirements for Shipments and Packaging," Code of Federal Regulations, Office of the Federal Register, February 2007.

49 CFR 174, 2006, "Carriage by Rail," Code of Federal Regulations, Office of the Federal Register, January 2006.

49 CFR 175, 2007, "Carriage by Aircraft," Code of Federal Regulations, Office of the Federal Register, February 2007.

49 CFR 176, 2007, "Carriage by Vessel," Code of Federal Regulations, Office of the Federal Register, January 2007.

49 CFR 177, 2006, "Carriage by Public Highway," Code of Federal Regulations, Office of the Federal Register, October 2006.

49 CFR 178, 2007, "Specifications for Packaging," Code of Federal Regulations, Office of the Federal Register, February 2007.

54 FR 48184, 1989, "National Priorities List of Uncontrolled Hazardous Waste Sites; Final Rule," Federal Register, U.S. Environmental Protection Agency, November 21, 1989.

42 USC $\S 6901$ et seq., 1976, "Resource Conservation and Recovery Act (Solid Waste Disposal Act)," United States Code, October 21, 1976.

42 USC $\S 9601$ et seq., 1980, "Comprehensive Environmental Response, Compensation, and Liability Act of 1980 (CERCLA/Superfund)," United States Code, December 11, 1980.

Bartholomay, R. C., and B. V. Twining, 2000, Radiochemical and Chemical Constituents in Water from the Southern Boundary of the Idaho National Engineering and Environmental Laboratory to the Hagerman Area, Idaho 1999, U.S. Geological Survey Open File Report 00-399.

Bartholomay, R. C., B. J. Tucker, L. L. Knobel, and L. J. Mann, 2001, Radiochemical and Chemical Constituents in Water from Selected Wells South of the Idaho National Engineering and Environmental Laboratory, Idaho, U.S. Geological Survey Open File Report 01-138.

Beasley, T. M., L. D. Cecil, P. Sharma, P. W. Kubik, U. Fehn, L. J. Mann, and H. E. Gove, 1993,

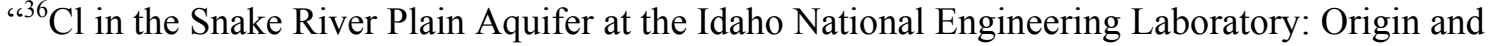
Implications," Ground Water, Vol. 31, No. 2, pp. 302-310. 
Beasley, T. M., P. R. Dixon, and L. J. Mann, 1998, “" ${ }^{\circ 9}$ Tc, ${ }^{236} \mathrm{U}$, and ${ }^{237} \mathrm{~Np}$ in the Snake River Aquifer at the Idaho National Engineering and Environmental Laboratory, Idaho Falls, Idaho," Environmental Science and Technology, Vol. 32, No. 24, pp. 3875-3881.

Busenberg, E., L. N. Plummer, and R. C. Bartholomay, 2001, Estimated Age and Source of the Young Fraction of Ground Water at the Idaho National Engineering and Environmental Laboratory, USGS Water Resources Investigations Report 01-4265.

Cecil, L. D, L. F. Hall, and J. R. Green, 2003, Reevaluation of Background Iodine-129 Concentrations in Water from the Snake River Plain Aquifer, Idaho, USGS Water Resources Investigations Report 03-4106.

Cecil, L. D, J. A. Welhan, J. R. Green, S. K. Grape, and E. R. Sudicky, 2000, "Use of Chlorine-36 to Determine Regional-scale Aquifer Dispersivity, Eastern Snake River Plain Aquifer, Idaho/USA," Nuclear Instruments and Methods in Physics Research, B 172, pp. 679-687.

DOE-ID, 1991, Federal Facility Agreement and Consent Order for the Idaho National Engineering Laboratory, Administrative Docket No. 1088-06-0629-120, U.S. Department of Energy Idaho Operations Office, U.S. Environmental Protection Agency, and Idaho Department of Health and Welfare, December 1991.

DOE-ID, 1992a, Record of Decision-Technical Support Facility (TSF) Injection Well (TSF-05) and Surrounding Groundwater Contamination (TSF-23), Document ID: 5202, U.S. Department of Energy Idaho Operations Office, U.S. Environmental Protection Agency, and Idaho Department of Health and Welfare, September 1992.

DOE-ID, 1992b, Record of Decision for Operable Unit 2-12, TRA Perched Water System, Document ID: 5230, U.S. Department of Energy Idaho Operations Office, U.S. Environmental Protection Agency, and Idaho Department of Health and Welfare, December 1992.

DOE-ID, 1995a, Record of Decision-Technical Support Facility (TSF) Injection Well (TSF-05) and Surrounding Groundwater Contamination (TSF-23) and Miscellaneous No Action Sites Final Remedial Action, Document ID: 10139, U.S. Department of Energy Idaho Operations Office, U.S. Environmental Protection Agency, and Idaho Department of Health and Welfare, August 1995.

DOE-ID, 1995b, Record of Decision Declaration for Central Facilities Area Landfills I, II, and III (Operable Unit 4-12), and No Action Sites (Operable Unit 4-03), Document ID: 10146, U.S. Department of Energy Idaho Operations Office, U.S. Environmental Protection Agency, and Idaho Department of Health and Welfare, October 1995.

DOE-ID, 1997, Final Record of Decision-Test Reactor Area, OU 2-13, Idaho National Engineering and Environmental Laboratory, DOE/ID-10586, U.S. Department of Energy Idaho Operations Office, U.S. Environmental Protection Agency, and Idaho Department of Health and Welfare, December 1997.

DOE-ID, 1999a, Record of Decision-Test Area North, Operable Unit 1-10, DOE/ID-10682, U.S. Department of Energy Idaho Operations Office, U.S. Environmental Protection Agency, and Idaho Department of Health and Welfare, October 1999. 
DOE-ID, 1999b, Final Record of Decision (ROD) Idaho Nuclear Technology and Engineering Center (INTEC) Operable Unit (OU) 3-13, DOE/ID-10660, Rev. 0, U.S. Department of Energy Idaho Operations Office, U.S. Environmental Protection Agency, and Idaho Department of Health and Welfare, October 1999.

DOE-ID, 2000, Comprehensive Remedial Investigation/Feasibility Study for the Central Facilities Area Operable Unit 4-13 at the Idaho National Engineering and Environmental Laboratory, DOE/ID-10680, Rev. 1, U.S. Department of Energy Idaho Operations Office, July 2000.

DOE-ID, 2002a, Waste Area Group 10, Operable Unit 10-08, Remedial Investigation/Feasibility Study Work Plan (FINAL), DOE/ID-10902, Rev. 0, U.S. Department of Energy Idaho Operations Office, August 2002.

DOE-ID, 2002b, Record of Decision Experimental Breeder Reactor-I/Boiling Water Reactor Experiment Area and Miscellaneous Sites Operable Units 6-05 and 10-04 Idaho National Engineering and Environmental Laboratory, DOE/ID-10980, Rev. 0, U.S. Department of Energy Idaho Operations Office, November 2002.

DOE-ID, 2004a, Waste Area Group 10, Operable Unit 10-08, Remedial Investigation/Feasibility Study Annual Report for Fiscal Year 2003, DOE/ID-11116, Rev. 0, U.S. Department of Energy Idaho Operations Office, April 2004.

DOE-ID, 2004b, Waste Area Group 10, Operable Unit 10-08, Remedial Investigation/Feasibility Study Supplemental Annual Report for Fiscal Year 2003, DOE/NE-ID-11116 SUPP, Rev. 0, U.S. Department of Energy Idaho Operations Office, August 2004.

DOE-ID, 2004c, Second Addendum to the Work Plan for the OU 7-13/14 Waste Area Group 7 Comprehensive Remedial Investigation/Feasibility Study, DOE/ID-11039, Rev. 0, U.S. Department of Energy Idaho Operations Office, August 2004.

DOE-ID, 2005, Waste Area Group 10, Operable Unit 10-08, Remedial Investigation/Feasibility Study Annual Status Report for Fiscal Year 2004, DOE/NE-ID-11198, Rev. 0, U.S. Department of Energy Idaho Operations Office, March 2005.

DOE-ID, 2006a, Quality Assurance Project Plan for Waste Area Groups 1, 2, 3, 4, 5, 6, 7, 10, and Deactivation, Decontamination, and Decommissioning, DOE/ID-10587, Rev. 9, U.S. Department of Energy Idaho Operations Office, July 2006.

DOE-ID, 2006b, Waste Area Group 10, Operable Unit 10-08, Remedial Investigation/Feasibility Study Annual Status Report for Fiscal Year 2005, DOE/NE-ID-11274, Rev. 0, U.S. Department of Energy Idaho Operations Office, April 7, 2006.

EPA, 1993, "Statement of Work for Inorganic Analysis-Multi-media, Multi-Concentration, Contract Laboratory Program,” ILM03.0, U.S. Environmental Protection Agency, June 1993.

EPA, 2000, “Guidance for the Data Quality Objective Process,” EPA QA/G-4, U.S. Environmental Protection Agency, August 2000.

ICP, 2004a, Central Facilities Area Landfills I, II, and III Annual Monitoring Report (2003), ICP/EXT-04-00149, Rev. 0, Idaho National Laboratory, Idaho Completion Project, October 2004. 
ICP, 2004b, Annual Groundwater Monitoring Status Report for Waste Area Group 5 for Fiscal

Year 2004, ICP/EXT-04-00369, Rev. 1, Idaho National Laboratory, Idaho Completion Project, November 2004.

ICP, 2005, Operable Unit 10-08 Prioritization of Drilling Locations for Fiscal Year 2005 and Outyears, ICP/EXT-04-00705, Rev. 0, Idaho National Laboratory, Idaho Completion Project, May 2005.

Idaho Code § 39-4401 et seq., 1983, "Hazardous Waste Management Act of 1983," State of Idaho, Boise, Idaho.

Knobel, L. L., B. R. Orr, and L. D. Cecil, 1992, "Summary of Concentrations of Selected Radiochemical and Chemical Constituents in Groundwater from the Snake River Plain Aquifer, Idaho: Estimated from an Analysis of Previously Published Data," Journal of Idaho Academy of Science, Vol. 28, No. 1, pp. 48-61, June 1992.

Mann, Larry J., and T. M. Beasley, 1994, I-129 in the Snake River Plain Aquifer at and near the Idaho National Engineering Laboratory, Idaho, 1990-91, U.S. Geological Survey Water Resources Report 94-4053.

MCP-1390, 2007, "Waste Generator Services Waste Management," Rev. 2, Idaho Cleanup Project, Idaho National Laboratory, February 2007.

MCP-1396, 2007, "Waste Generator Services Management of CERCLA Waste for Disposal at ICDF," Rev. 6, Idaho Cleanup Project, Idaho National Laboratory, February 2007.

MCP-3475, 2006, “Temporary Storage of CERCLA-Generated Waste at the INL Site," Rev. 5, Idaho Cleanup Project, Idaho National Laboratory, November 2006.

PLN-2128, 2006, "Miscellaneous Sites Cleanup Project Health and Safety Plan," Rev. 2, Idaho National Laboratory, Idaho Cleanup Project, October 2006.

Rattray, G. W., and L. J. Campbell, 2003, Radiochemical and Chemical Constituents in Water from the Southern Boundary of the Idaho National Engineering and Environmental Laboratory to the Hagerman Area, Idaho 2002, U.S. Geological Survey Open File Report 2004-1004.

Twining, B. V., and G. W. Rattray, 2003, Radiochemical and Chemical Constituents in Water from Selected Wells and Springs the Southern Boundary of the Idaho National Engineering and Environmental Laboratory to the Hagerman Area, Idaho 2001, U.S. Geological Survey Open File Report 03-168.

USGS, 1999, Chemical Constituents in Ground Water from 39 Selected Sites with an Evaluation of Associated Quality Assurance Data, Idaho National Engineering and Environmental Laboratory and Vicinity, Idaho, U.S. Geological Survey Open File Report 99-246. 